\title{
PRIMARY SUCCESSION AND FOREST DEVELOPMENT ON COASTAL LAKE MICHIGAN SAND DUNES
}

\author{
JOHN LICHTER ${ }^{1}$ \\ Department of Ecology, Evolution, and Behavior, University of Minnesota, St. Paul, Minnesota 55108 USA and \\ The University of Michigan Biological Station, Pellston, Michigan 49769 USA
}

\begin{abstract}
Vegetation and soil properties were described across a well-dated sand-dune chronosequence bordering northern Lake Michigan to document patterns and rates of primary succession and forest ecosystem development, and to determine environmental constraints that potentially drive succession and regulate species diversity. The site experienced frequent and continuing formation of 72 shore-parallel dune ridges over the past $2375 \mathrm{yr}$. Across the chronosequence represented by the youngest 13 dune ridges aged 25-440 yr, there were clear patterns of species turnover and community convergence as well as successional changes in species diversity, aboveground biomass, aboveground litter production, net ecosystem production, nutrient pools, and nutrient cycling. Dune-building species were replaced by evergreen shrubs and bunchgrass within $100 \mathrm{yr}$, which in turn, were replaced by mixed pine forest within $345 \mathrm{yr}$. Plant-species richness increased to a peak in developing forest at $285 \mathrm{yr}$ but thereafter decreased as early-successional species disappeared from the communities. Rates of species addition peaked between 95 and $145 \mathrm{yr}$ as forest species invaded, whereas rates of species loss peaked between 345 and $440 \mathrm{yr}$ as early-successional species were lost from the developing forest.

Development of the forest ecosystem required $\sim 300 \mathrm{yr}$ (i.e., 145-440 years). Total ecosystem carbon increased in a logistic manner to $128 \mathrm{Mg} \mathrm{C} / \mathrm{ha}$, with net ecosystem production peaking at $30 \mathrm{~g} \mathrm{C} \cdot \mathrm{m}^{-2} \cdot \mathrm{yr}^{-1}$ in developing forest. Aboveground biomass and $\mathrm{O}$ horizon mass increased to $\sim 137 \mathrm{Mg} / \mathrm{ha}$ and $\sim 79 \mathrm{Mg} / \mathrm{ha}$, respectively, whereas aboveground litter production increased to $3.5 \mathrm{Mg} \cdot \mathrm{ha}^{-1} \cdot \mathrm{yr}^{-1}$ at $440 \mathrm{yr}$, but thereafter varied between 175 and $350 \mathrm{Mg} \cdot \mathrm{ha}^{-1} \cdot \mathrm{yr}^{-1}$. Total carbon and total nitrogen in the upper $15 \mathrm{~cm}$ of mineral soil and $\mathrm{O}$ horizon accumulated to $\sim 42 \mathrm{Mg} / \mathrm{ha}$ and $\sim 1.36 \mathrm{Mg} / \mathrm{ha}$, respectively. Estimated average rates of carbon and nitrogen accumulation over $440 \mathrm{yr}$ of ecosystem aggradation were $23.2 \mathrm{~g} \cdot \mathrm{m}^{-2} \cdot \mathrm{yr}^{-1}$ for carbon and 0.38 $\mathrm{g} \cdot \mathrm{m}^{-2} \cdot \mathrm{yr}^{-1}$ for nitrogen. Because nitrogen-fixing plants are rare on the upland dune ridges, ecosystem aggradation depends largely on atmospheric nitrogen inputs. Following colonization by conifers, soil acidification resulted in rapid leaching losses of calcium and magnesium, whereas phosphorus and potassium were cycled more tightly.

The dune chronosequence represents a complex gradient of changing environmental constraints that differentially reduce the survival, growth, and reproduction of plant species. Young dune ridges near the lake shore are characterized by strong winds, sand burial and erosion, high insolation, high rates of evaporation, and low availability of nitrogen and phosphorus. These conditions ameliorate with increasing dune age as wind velocities and sand movement diminish with distance from the lake, as accumulating organic matter improves the moistureholding capacity and nitrogen availability of the soil, and as mineral weathering mobilizes soil phosphorus. However, in developing forest, light and cationic nutrients may become limiting, and decreased light availability, cool soil temperatures, and accumulation of a thick forest floor may limit recruitment from seed for many species. These numerous potential environmental constraints suggest a considerable complexity in this ostensibly simple ecosystem.
\end{abstract}

Key words: aboveground biomass accumulation; aboveground litter production; chronosequence; coniferous forest; community convergence; diversity-environment relations; net ecosystem production; nitrogen; phosphorus; primary succession; soil development; species diversity.

\section{INTRODUCTION}

Soil chronosequences of different-aged geologic substrates are valuable tools for investigating slow pro-

Manuscript received 20 August 1997; revised 28 November 1997; accepted 6 December 1997; final version received 8 January 1998.

${ }^{1}$ Present address: Department of Botany, Duke University, Durham, North Carolina 27708 USA cesses such as primary succession and forest ecosystem development. Chronosequence studies have shown that patterns of primary succession depend on the interplay among plant life history traits, probabilistic colonization, species interactions, and autogenic environmental change (Walker et al. 1986, Walker and Chapin 1986, Chapin et al. 1994). A sound understanding of primary succession may be important for promoting recovery of degraded ecosystems (Cairns 1980), which can be 
more similar to primary than to secondary succession (Tilman 1988), and for predicting patterns of forest migration during periods of future climate change (Davis 1989). Forest expansion into grassland or tundra biomes is analogous to tree invasion of shrub and grass communities during primary succession; thus primary successions may provide model systems with which to study potential mechanisms and consequences of forest migration.

Although much has been learned about primary succession and ecosystem development from chronosequences, their use entails an implicit assumption that changes in vegetation and soil properties across a particular chronosequence represent the developmental history at any site within the chronosequence (Drury and Nisbet 1973, Pickett 1989). In order for this to be true, initial conditions and pathways of succession must have been similar at each site within the chronosequence. This assumption is suspect where variation in topography, soil parent material, soil seed bank, climate, disturbance regime, and priority effects such as the order of species invasion might have differentially affected the development of community and ecosystem properties (Pickett 1989). Although this assumption is probably violated at most sites, it is rarely tested because fossil records from which local vegetation and disturbance histories can be reconstructed for individual sites within a chronosequence generally do not exist. The single study that achieved this showed that vegetation changes across the classic Glacier Bay chronosequence did not represent the pathway of succession at each site within the chronosequence (Fastie 1995). Instead multiple pathways of composition change were documented that were associated with historical differences in the distance-to-seed sources of late-successional species.

Coastal Lake Michigan sand dunes form unique soil chronosequences in which the assumptions for interpreting chronosequences may be largely met. Variation in soil texture is minimal because selective transport of specific grain sizes by wind provides a uniformly textured soil parent material (Franzmeier and Whiteside 1963). Variation in topography can be controlled by sampling vegetation and soil properties at similar aspect and topographic position across a dune chronosequence. Also, sand dunes do not initially contain soil seed banks. Seeds of colonizing species must disperse from older to younger dunes against the prevailing onshore wind direction. Therefore, the direction of seed sources remains relatively constant through time, and if dunes form at regular intervals, then the distance-to-seed sources may also remain relatively constant. Dune successions may also be affected minimally by climate change. Daily, seasonal, and annual temperature fluctuations are buffered by Lake Michigan (Changnon and Jones 1972, Eichenlaub et al. 1990); consequently, climatic trends may have reduced effects on succession.
This paper documents long-term community and ecosystem development across a well-dated chronosequence of stable sand dunes bordering northern Lake Michigan. The site presents an unusual opportunity to investigate primary succession and forest ecosystem development by integrating observational, experimental, and paleoecological studies. Over the past $3500 \mathrm{yr}$, 108 shore-parallel dune ridges formed, averaging one every $32 \mathrm{yr}$. This high frequency of dune formation relative to the time scale of primary succession resulted in clear patterns of species turnover and forest ecosystem development. Moreover, wetlands developing in the interdunal swales that separate most adjacent dune ridges preserved fossil records of the surrounding vegetation. These fossil records allow reconstruction of local vegetation and disturbance histories to extend patterns of succession into the past. This site represents a model system in which the effects of several common sources of variability in successional patterns are eliminated or reduced. The objectives of this study were (1) to document patterns and rates of community and forest ecosystem development across the dune chronosequence, (2) to determine how much of the dune chronosequence represents primary succession, and (3) to determine environmental changes that potentially influence primary succession and regulate species diversity. A chronology of dune formation was developed with radiocarbon dates, tree ages, and historical information (Lichter 1995, 1997). I report changes in vegetation and soil properties measured in replicated survey plots spanning $2375 \mathrm{yr}$ of the dune chronosequence, and interpret successional patterns by plotting vegetation and ecosystem properties against estimated dune age.

\section{Study Site}

The dune chronosequence is located at Wilderness State Park (WSP) in Emmet County of northern lower Michigan (Fig. 1). The park borders Lake Michigan on the west and the Straits of Mackinac on the north. Mackinaw City, $17 \mathrm{~km}$ east on the Straits of Mackinac, averaged $6.2^{\circ} \mathrm{C}$ and $772.2 \mathrm{~mm}$ of annual precipitation between 1951 and 1980, and Cross Village, $12 \mathrm{~km}$ south on the coast of Lake Michigan, averaged 731.5 $\mathrm{mm}$ of annual precipitation during the same period (Nurnberger 1996). The park lies between 177 and 225 $\mathrm{m}$ elevation (0-50 $\mathrm{m}$ above mean lake level) and consists of lake plains that developed during and since the mid-Holocene Nipissing high-water lake stages (38005500 yr BP) (Spurr and Zumberge 1956). On the east shore of Lake Michigan, an extensive strandplain of $\sim 108$ arcuate dune ridges (i.e., dune-capped beach ridges) formed over the past $3500 \mathrm{yr}$ (Fig. 2). The dune ridges are $\sim 2.5 \mathrm{~km}$ long, $10-30 \mathrm{~m}$ wide, and generally between 3 and $5 \mathrm{~m}$ in height. Interdunal swales developed open-pond vegetation, peatlands, or conifer swamp communities. The ridge and swale topography characterizes several Lake Michigan embayments re- 


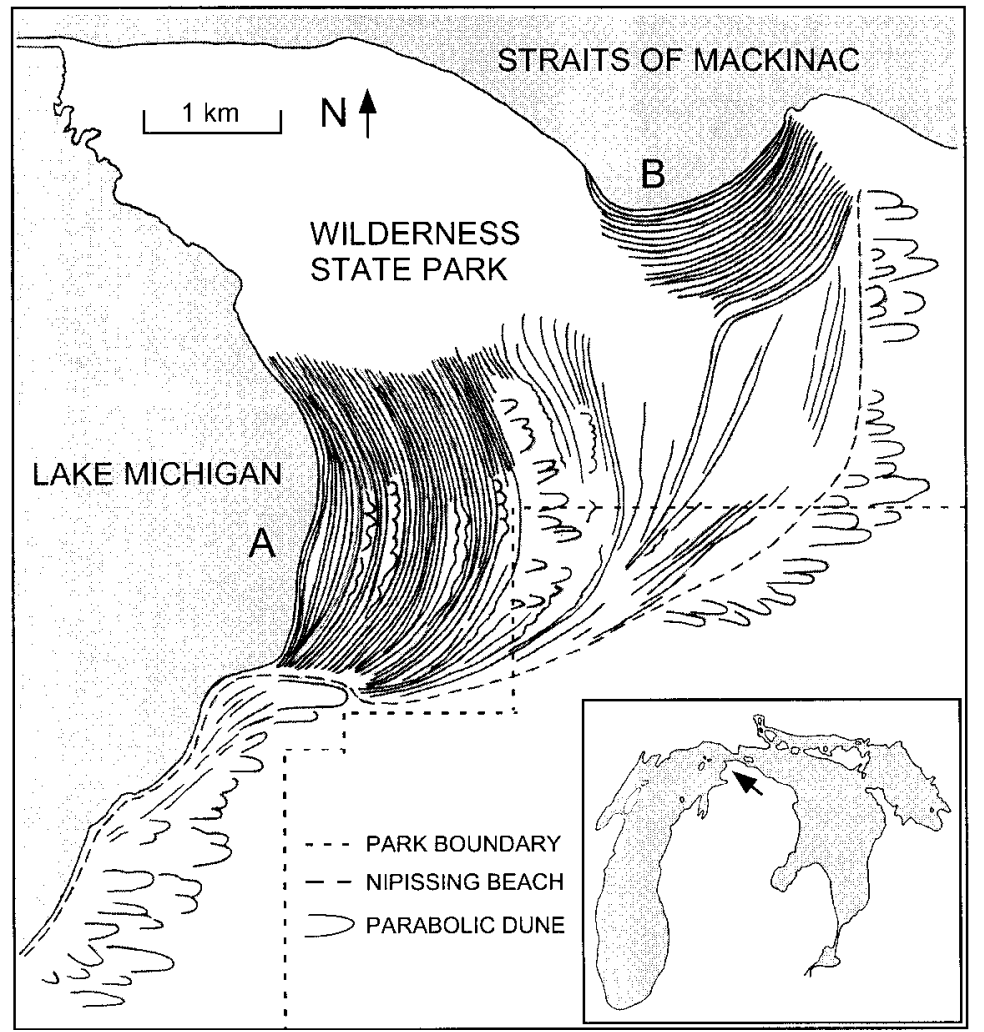

FIG. 1. Map showing location of Wilderness State Park in northern lower Michigan. Two dune-ridge complexes labeled $\mathrm{A}$ and $\mathrm{B}$ are shown. This study was conducted in the northern portion of complex A.

ceiving longshore sediments over thousands of years (e.g., Thompson 1992, Dott and Mickelson 1995, Petty et al. 1996).

Shore-parallel dune ridges form during episodes of falling and low lake level as sand deposited on the widened beach is transported shoreward by wind and trapped by plants in front of the previously established dune ridge (Olson 1958a, Lichter 1995). Embryonic dunes developing on the widened beach coalesce into a continuous ridge above the upper reach of waves. Plants participate in the formation and secondary development of coastal sand dunes. During episodes of high lake level and wave erosion, the ability of plants to promote stabilization determines whether dunes retain their shore-parallel orientation or develop blowouts that eventually form slowly moving parabolic dunes (Pye 1990). At WSP, parabolic dunes span the entire coast along the 2375- and 3200-yr-old dune ridges, which developed during major lake-level transgressions (Lichter 1995; Fig. 2). However, in the time since $2375 \mathrm{yr} \mathrm{BP}$, parabolic dunes formed only in the central portion of the dune complex, indicating that wave and wind erosion were less extreme, and that dune ridges in the northern and southern portions of the complex have been stable since their formation (Fig. 2). This point is important. If dune surfaces were destabilized more than a few decades after their formation, then radiocarbon estimates of dune age would not rep- resent ecosystem age. I therefore measured vegetation and soil properties only in the northern portion of the dune complex through the 2375-yr-old dune ridge.

The dune-ridge chronosequence at WSP contrasts with the Indiana Dunes, site of the classic studies of dune succession (Cowles 1899, Olson 1958b) in two important ways. At WSP, 72 dune ridges formed over the past $2375 \mathrm{yr}$ compared with $\sim 20$ dune ridges and parabolic dunes that formed over the past $12000 \mathrm{yr}$ at the Indiana Dunes (Olson 1958b). Greater rates of dune formation at WSP provide a higher resolution chronosequence across which gradational changes in vegetation and soil properties can be measured. Also, dune ridges in the northern and southern portions of the chronosequence at WSP have remained geomorphically stable since their formation, whereas many dunes at the Indiana Dunes National Lakeshore have been repeatedly disturbed by logging, fire, and human trampling over the past century and a half and have not remained geomorphically stable (Cowles 1899; Olson 1958b).

\section{Chronology of dune formation at Wilderness State Park}

I developed a chronology of dune-ridge formation at WSP with radiocarbon dates, estimates of the ages of pioneer trees, and information from the original 1840 land survey (Lichter 1995, 1997). Roots and rhizomes, presumably of beach grass, Ammophila breviligulata, 


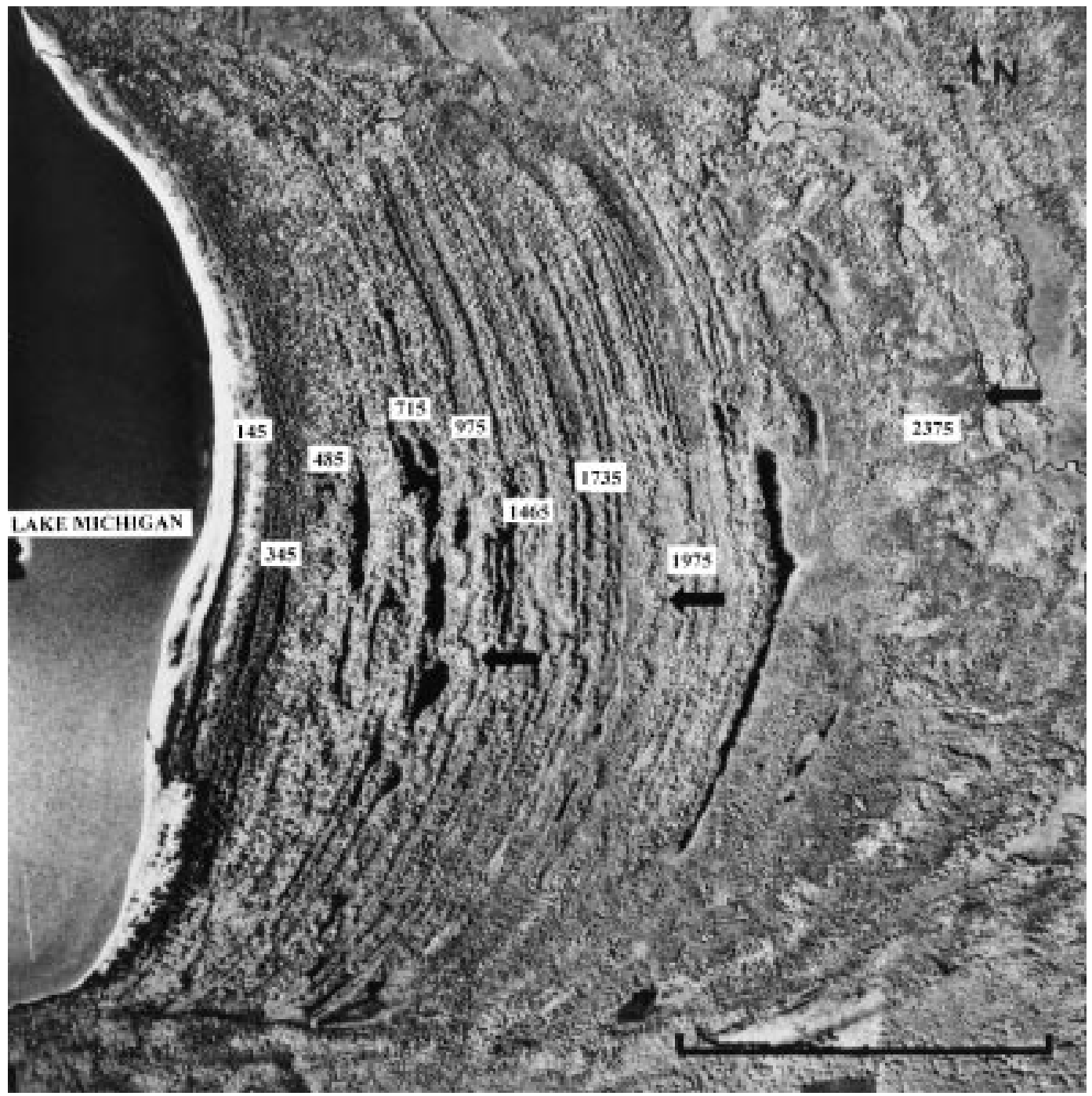

FIG. 2. Aerial photograph of dune-ridge complex A. Selected ages across the sequence are shown. Arrows indicate Ushaped parabolic dunes that developed during episodes of dune destabilization associated with high lake levels. Reprinted from Geoderma 85:255-282, 1998, with permission from Elsevier Science.

were collected in sediment cores from interdunal wetlands at 10 locations spaced uniformly across the dune complex. The roots and rhizomes were dated with accelerator mass spectroscopy (AMS) radiocarbon techniques, which allow a small sample of identifiable organic material to be dated. Beach grass is the principal dune-forming plant species, and its belowground parts are preserved at the base of each dune ridge by the shallow water table (Lichter 1997). This chronology shows that $\sim 108$ dune ridges formed over the past 3500 yr, and that ridge formation occurred relatively uniformly during this time period. That is, there were no extended periods of centuries in which ridges were not constructed. Aerial photographs show that the currently active dune ridge (i.e., the first dune ridge adjacent to the present lake shore that annually accumulates sand) formed in the $1960 \mathrm{~s}$ during a precipitous lake-level recession associated with regional drought (Lichter 1995). Estimates of tree ages and information about the position of the shoreline from the original land survey indicate that the next four dune ridges formed since 1840 , each in response to regional drought (Lichter 1995). These recent episodes of dune formation imply that the processes of primary succession are ongoing and active at this site.

\section{Methods}

\section{Vegetation properties}

Vegetation properties were measured across four transects intersecting the northern portion of the dune chronosequence. Along each transect, $20 \times 31.25 \mathrm{~m}$ $\left(625 \mathrm{~m}^{2}\right)$ survey plots were placed on the 25-, 55-, 95-, 145-, 175-, 225-, 285-, 345-, 400-, 440-, 835-, 
1465-, 1975-, and 2375-yr-old ridges. The survey plots were concentrated on dune ridges younger than $500 \mathrm{yr}$ because vegetation and ecosystem changes are most pronounced there. The diameter-at-breast-height (dbh) of all trees (defined as $\geq 5 \mathrm{~cm}$ dbh) was measured in each survey plot to estimate tree density, size, and basal area. Tree aboveground biomass was estimated from dbh data using allometric biomass regressions (Pastor et al. 1983/1984). I substituted the regression relationship obtained from white pine (Pinus strobus) for all species of conifers and the regression relationship obtained from yellow birch (Betula alleghaniensis) for paper birch (Betula papyrifera). Although these substitutions are not ideal, the resulting biomass estimates consider differences in wood density between conifers and hardwoods that are not considered in estimates of basal area. Aboveground biomass and aboveground litter production of the nonforested 25- and 95-yr-old dune ridges were estimated by clipping, drying, and weighing grasses in three $1-\mathrm{m}^{2}$ subplots within each $625-\mathrm{m}^{2}$ survey plot over a 2 -yr period. Annual aboveground litter production of forested ridges was estimated from litter collections using three $1-\mathrm{m}^{2}$ litter traps located in each survey plot over the same 2-yr period. Light penetration of the canopy was measured in micromoles PAR per square meter per second with a Sunflect Ceptometer (Decagon Devices, Incorporated, Pullman, Washington, USA). Readings were taken $1 \mathrm{~m}$ above the ground surface on a cloudless day (28 June 1994) at 10 locations in each survey plot and at a location near each survey plot exposed to full sunlight. Results are reported as the proportion of full sunlight penetrating the forest canopy in each survey plot.

The amount of aboveground biomass removed by selective pine logging during the late 19th century was estimated to determine if this disturbance had lasting effects on living and detrital biomass and species diversity. Pine stumps from 19th century logging remain at the site and were counted and measured to estimate the aboveground biomass of pine trees harvested. The dbh of stumps in the $625-\mathrm{m}^{2}$ survey plots was estimated by measuring the circumference of stumps at $0.3 \mathrm{~m}$ height and using linear regression relationships developed from living trees at the site to derive dbh at 1.3 $\mathrm{m}$ height. The dbh estimates were then used with the allometric biomass relationship for white pine to estimate the aboveground biomass of pine trees harvested in each survey plot. These estimates were used as the predictor variable in linear regression analyses testing whether the logging disturbance had lasting effects on aboveground biomass, O horizon mass, total species richness, and forest understory species richness.

To describe the distributions and abundances of plant species, community composition, and species diversity, the percent cover of each vascular plant species was estimated in $5 \times 20 \mathrm{~m}\left(100 \mathrm{~m}^{2}\right)$ strips located across the front or westward-facing dune slope in each 625$\mathrm{m}^{2}$ survey plot. Each of the $100-\mathrm{m}^{2}$ strips was subdi-
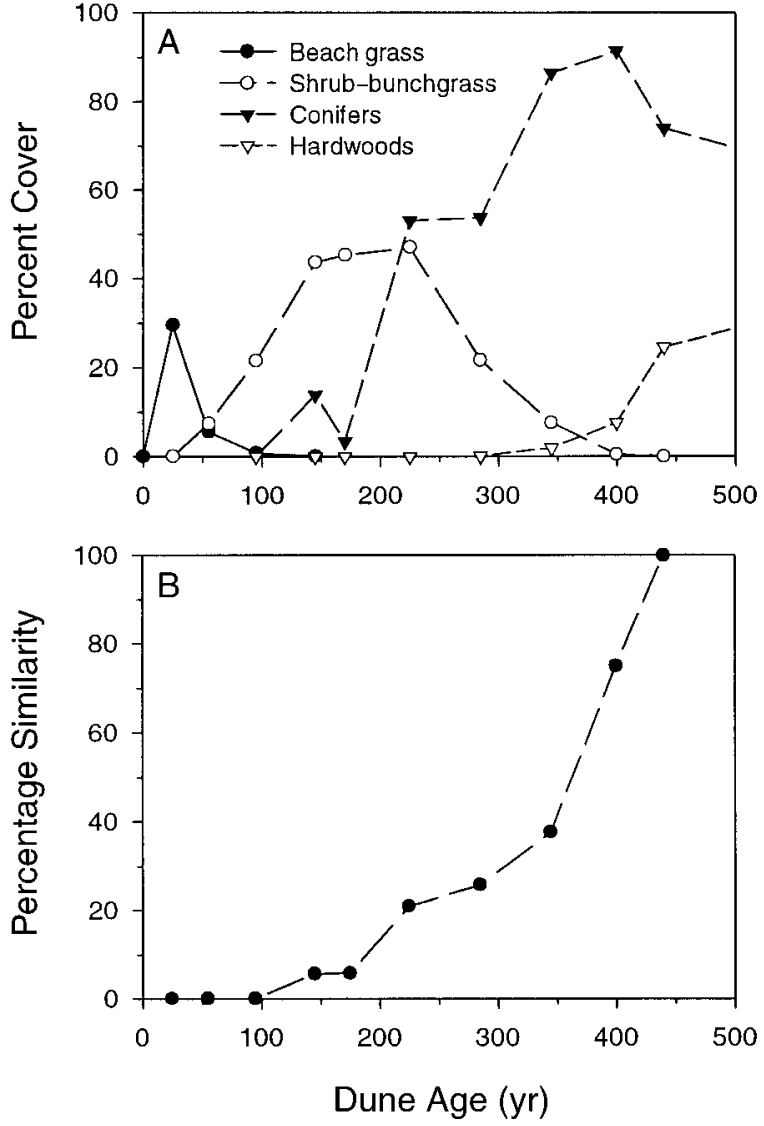

FIG. 3. Species turnover and community convergence during primary succession. (A) Changes in percent cover of the dominant species groups. (B) Percentage similarity between the community composition of each dune ridge $\leq 440$ $\mathrm{yr}$ old and that of the 440-yr-old dune ridge.

vided into four $25-\mathrm{m}^{2}$ sections, and the percent cover of vascular plant species including canopy species that extended over the area of the strip was estimated visually. I also estimated the percentage of ground surface that was bare sand, or was covered with lichens, mosses, or plants and plant litter. To determine whether community composition converged or diverged during succession, I summed percent cover data across the four survey plots on each of the surveyed dune ridges and calculated percentage similarity between the composition of dune ridges $\leq 440 \mathrm{yr}$ and the composition of the 440-yr-old dune ridge. Percentage similarity (PS) was calculated as $\sum_{i=1}^{m} \min \left(x_{i j}, x_{i 440}\right)$, where $x_{i j}$ is the relative percent cover of species $i$ on the $j$ th dune ridge and $x_{i 440}$ is the relative percent cover of species $i$ on the 440 -yr-old dune ridge, $\min \left(x_{i j}, x_{i 440}\right)$ is the smaller of $x_{i j}$ or $x_{i 440}$, and $m$ is the number of species in common for the two ridges (Pielou 1984). Species richness $(S)$ was calculated as the cumulative number of different species in the four survey plots on each of the surveyed dune ridges. Shannon-Weiner diversity $\left(H^{\prime}\right)$ and evenness $(J)$ were also calculated from percent cover data. Species were categorized as early-successional species 
characteristic of nonforested or open dunes $(\mathrm{Sd})$, forest canopy species (Sc), or forest understory species $(\mathrm{Su})$. Colonizing species $(I)$ are those entering in the succession for the first time, and species suffering local extinction $(E)$ are those not present on a particular dune ridge but present on the preceding dune ridge and not re-entering the succession on older dune ridges. Species turnover between consecutive dune ridges was calculated as the proportion of colonizing species plus those suffering local extinction of the total number of different species on both dune ridges $(I+E) / S_{\mathrm{T}}$. Average rates of species addition and loss between nearest surveyed ridges were determined by dividing $I$ and $E$ by the number of years between consecutive dune ridges.

\section{Soil properties}

Soil properties were described for 20 of the 72 dune ridges ranging between 25 and 2375 yr of age. Soil samples were collected in the $625-\mathrm{m}^{2}$ survey plots on the 14 ridges that were surveyed for vegetation properties and additionally on the 120-, 420-, 465, 485-, 715-, and 975-yr-old dune ridges. Samples were collected at three topographic positions: the front or westward-facing slope (FS); the ridge crest (C); and the back or eastward-facing slope (BS). I sampled the $\mathrm{O}$ horizon (forest floor) with a $7.6 \mathrm{~cm}$ diameter core and the upper $15 \mathrm{~cm}$ of mineral soil with a $2.5 \mathrm{~cm}$ diameter core. Beside each sample location, I used a soil probe to measure the thickness of the $\mathrm{O}$ horizon and the depth from top of mineral soil to the upper surface of the $B$ horizon. Depth to the upper B horizon is a simple measure of cumulative soil development that is easy to replicate in the field (Franzmeier and Whiteside 1963).

Mineral soil and $\mathrm{O}$ horizon samples were analyzed chemically to determine total pools of $\mathrm{C}, \mathrm{N}, \mathrm{P}, \mathrm{Ca}, \mathrm{Mg}$, and K. Mineral samples were weighed, oven-dried, and re-weighed to determine percentage moisture and field bulk density (grams per cubic centimeter). Three sets of subsamples were prepared for $\mathrm{pH}$ measurement, dry combustion, and wet digestion. Soil $\mathrm{pH}$ was measured with a digital meter on subsamples mixed 1:1 with distilled water. Subsamples for combustion were first soaked in $15 \%$ sulfurous acid to remove carbonates (Nelson and Sommers 1982) and were later combusted with a Perkin Elmer 2400 to determine C and N concentrations. Subsamples for wet digestion were composited by dune age and homogenized, then a $0.5-\mathrm{g}$ subsample was digested with $5 \mathrm{~mL}$ of a 6:1 mixture of concentrated nitric $\left(\mathrm{HNO}_{3}\right)$ and perchloric $\left(\mathrm{HClO}_{4}\right)$ acids at $125-130^{\circ} \mathrm{C}$ for $24 \mathrm{~h}$. The solutions were diluted to $35 \mathrm{~mL}$ with $25 \%$ nitric acid and were analyzed with integratively coupled plasma-atomic emission spectroscopy (ICP-AES) to determine concentrations of phosphorus and base cations. O horizon samples were dried and weighed to estimate mass and were analyzed similarly with ICP-AES. The resulting concentrations of soil nutrients in the upper mineral soil and $\mathrm{O}$ horizon

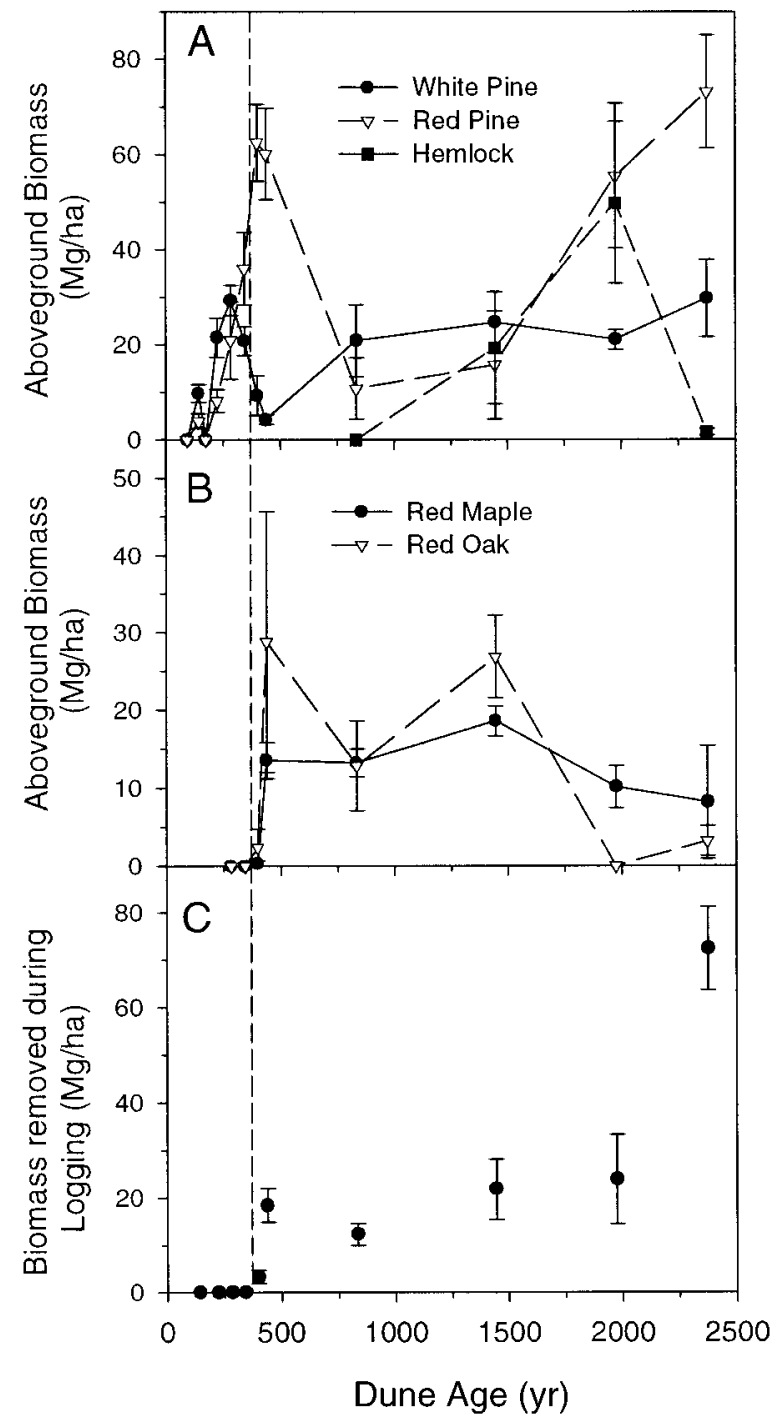

FIG. 4. Changes in the composition of the forest canopy (A, B) and estimates of the aboveground biomass removed during the 19th century logging disturbance (C). Vertical dashed line indicates break between pristine and logged-over dune ridges.

were converted to quantities and summed to estimate total nutrient pools.

The relative availability of soil $\mathrm{N}$ and $\mathrm{P}$ was measured using ion-exchange resin (IER). Ions in the soil solution adsorb to the exchange resin and can later be extracted and quantified (Binkley and Hart 1989). Two IER bags were placed in each of the four vegetation survey plots on 10 dune ridges. The resin bags were installed just below the surface of the mineral soil in June 1994 and were collected in November 1994. A 2g subsample of resin was extracted with $1 \mathrm{~mol} / \mathrm{L} \mathrm{KCl}$ and the solutions were analyzed for $\mathrm{NH}_{4}-\mathrm{N}, \mathrm{NO}_{3}-\mathrm{N}$, and $\mathrm{PO}_{4}-\mathrm{P}$ with a Lachat Autoanalyzer (Lachat Instruments, Incorporated, Milwaukee, Wisconsin, USA). 


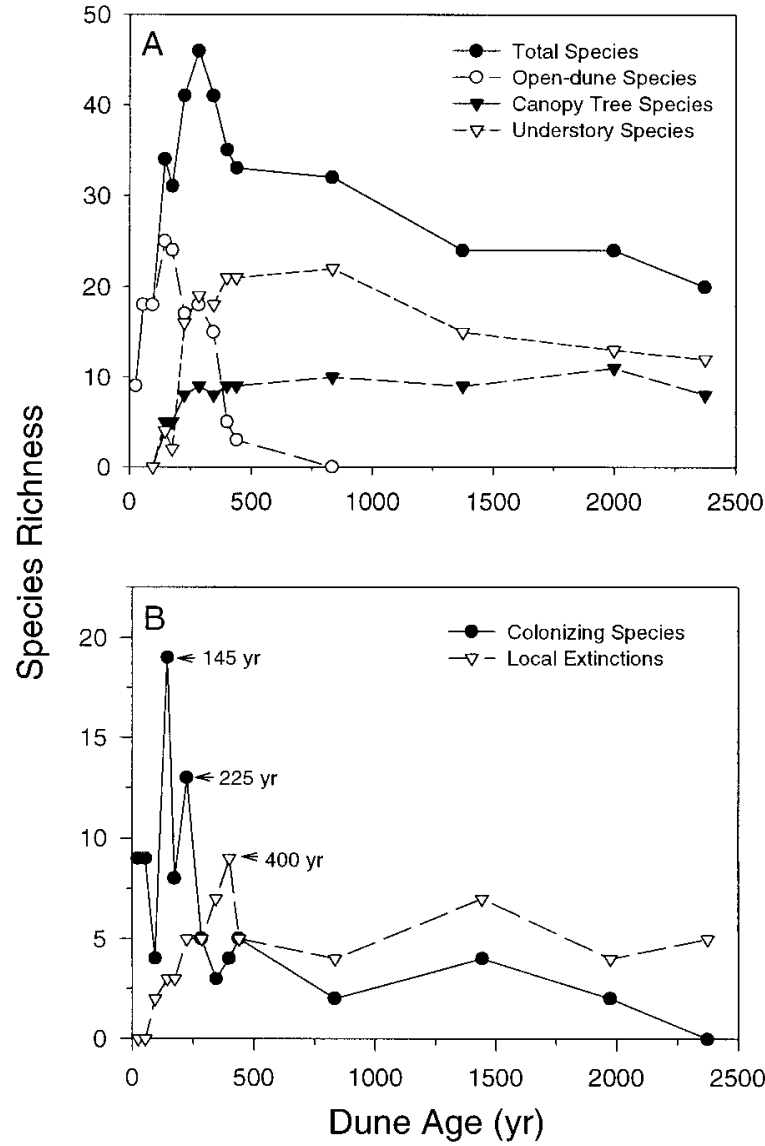

FIG. 5. Successional changes in species richness. (A) Total species richness and total richness of species groups. (B) Numbers of colonizing species and local extinctions.

\section{Net ecosystem production}

Total ecosystem carbon was estimated from measured $\mathrm{C}$ concentrations in the upper soil horizons and from estimates of aboveground and belowground biomass. Total root biomass was estimated with regression models compiled for conifer and hardwood species that predict root biomass from aboveground biomass (Kurz et al. 1996). The regression relationship for conifers was $\mathrm{RB}_{\text {con }}=0.2317 \mathrm{AB}_{\text {con }}$ and the relationship for hardwoods was $\mathrm{RB}_{\text {hdws }}=e^{0.359} \mathrm{AB}_{\text {hdws }}^{0.639}$. Biomass estimates were multiplied by 0.5 to estimate $\mathrm{C}$ content (Schlesinger 1977). Total biomass $\mathrm{C}$ and total soil $\mathrm{C}$ were summed to approximate ecosystem $\mathrm{C}$ for each of the surveyed dune ridges. These calculations underestimate ecosystem $\mathrm{C}$ because carbon contained in forest understory biomass and in soil horizons deeper than $15 \mathrm{~cm}$ below the surface of the mineral soil were not included. Ecosystem $\mathrm{C}$ was plotted against estimated dune age and fitted with a logistic model to determine net ecosystem production, which is the derivative of the fitted model.

To determine the importance of symbiotic $\mathrm{N}$ fixation in ecosystem aggradation, I compared the average an- nual rate of $\mathrm{N}$ accumulation through $440 \mathrm{yr}$ of ecosystem development with measured atmospheric inputs of $\mathrm{N}$ at the University of Michigan Biological Station, which is $26 \mathrm{~km}$ inland. Total quantities of ecosystem $\mathrm{N}$ were estimated from $\mathrm{N}$ concentrations of the upper mineral soil and the $\mathrm{O}$ horizon and from estimates of the $\mathrm{N}$ content of biomass. The $\mathrm{N}$ content of biomass was estimated using an allometric carbon-to-N ratio of 143:1 compiled from northern/alpine coniferous forest biomes (Vitousek et al. 1988). The average annual rate of ecosystem $\mathrm{N}$ accumulation was calculated by dividing total ecosystem $\mathrm{N}$ by $440 \mathrm{yr}$ of accumulation.

\section{Physical environment}

Sand burial and erosion, wind velocity, evaporation, and soil drying were measured on young dune ridges to determine physical stresses that may influence plants during primary succession. I measured sand movement each year between 1990 and 1996. Bamboo stakes were inserted into the sand until a marked node was even with the dune surface. Forty stakes were placed haphazardly on the first ridge; 40 across both of the second and third dune ridges along a section of the coast where these ridges are not separated by an interdunal swale; and 40 across both of the fourth and fifth dune ridges. The stakes were checked every April and September, and sand movement was measured as change in the elevation of the dune surface relative to its original elevation. The stakes were about the same diameter as stems of early-successional shrubs and probably had a similar influence on sand movement. I measured wind velocity and evaporation on the crests of the first, fifth, and eighth dune ridges and in the third interridge swale. Measurements were made with a hand-held anemometer at shoulder height $(1.5 \mathrm{~m})$ and at the ground surface $(6.0-11.5 \mathrm{~cm})$ to determine the percentage attenuation of wind velocity by the vegetation and topography. I measured evaporation by placing a measured volume of water in pie tins, leaving the tins out for several hours during the day, and recording the volume of water remaining. Differential rates of soil drying were measured at two depths $(0-5 \mathrm{~cm}$ and $10-15 \mathrm{~cm})$ and at four locations (the first dune ridge, the first interridge swale, the nonforested fifth ridge, and the forested eleventh dune ridge) by collecting soil samples for $4 \mathrm{~d}$ following $3 \mathrm{~d}$ of heavy rainfall in July 1994 and gravimetrically measuring the change in percentage soil moisture.

\section{Diversity-environment relations}

Species richness was plotted against several environmental variables related to productivity to determine potential environmental controls of diversity. Because the data are ordered by dune age, successional trajectories along diversity-environment relationships were drawn to illustrate environmental changes during primary succession that potentially regulate plant diversity. I plotted species richness as a function of aboveground biomass, light availability, percentage 

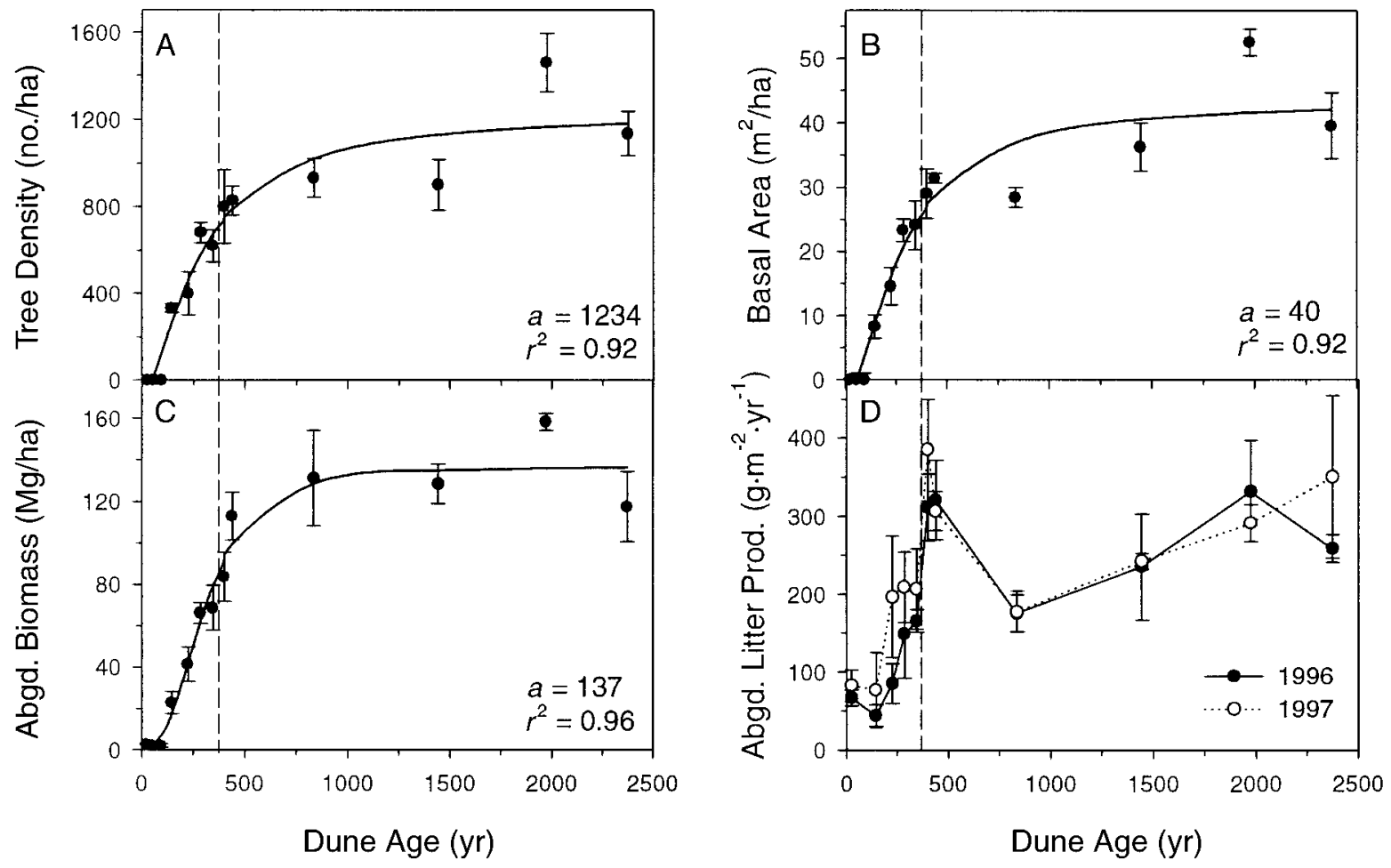

FIG. 6. Successional changes in tree density (A), basal area (B), aboveground biomass (C), and aboveground litter production (D) measured across the dune chronosequence. Data are means $( \pm 1 \mathrm{SE})$ of four $625-\mathrm{m}^{2}$ survey plots per dune ridge. A logistic model was fitted to data to describe increases in tree density, basal area, and aboveground biomass as a function of time. The asymptote $(a)$ and the coefficient of determination $\left(r^{2}\right)$ are given for each relationship. Vertical lines indicate logging as in Fig. 4.

soil moisture, total soil $\mathrm{N}$, total soil $\mathrm{Ca}$, and total soil $\mathrm{P}$, and used first- and second-order regression equations to model the relationships.

\section{RESULTS}

\section{Vegetation properties}

Vegetation surveys revealed clear patterns of successional change in species distributions and abun-

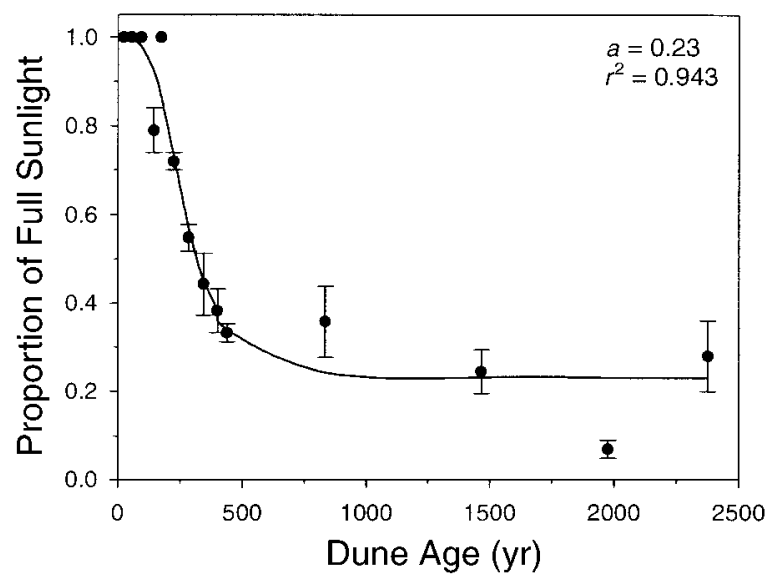

FIG. 7. Proportion of full sunlight reaching the forest understory ( $1 \mathrm{~m}$ above ground surface). Data are means $( \pm 1$ $\mathrm{SE}, n=4)$. The asymptote $(a)$ and the coefficient of determination $\left(r^{2}\right)$ are given for the fitted model. dances similar to succession described at the Indiana Dunes (Cowles 1899, Olson 1958b). Species generally entered the succession in low abundance, increased to a peak, and later either decreased to local extinction or remained a component of the mixed pine forest (Table $1)$. The first dune ridge ( $25 \mathrm{yr}$ ) was dominated by beach grass (Ammophila breviligulata) but other dune-building species such as willow shrubs (Salix spp.) and sand cherry (Prunus pumila) were also present. Beach grass declined rapidly on older dune ridges that do not accrete sand annually (Fig. 3A). Evergreen shrubs such as bearberry (Arctostaphylos uva-ursi) and juniper ( $\mathrm{J} u$ niperus communis), and little bluestem bunchgrass (Schizachyrium scoparium) dominated open dune ridges (55-175 yr) prior to development of mixed pine forest (225-440 yr). Comparisons of percentage similarity between dune ridges $\leq 440 \mathrm{yr}$ old and the 440 yr-old dune ridge showed gradual convergence toward the composition of mixed pine forest (Fig. 3B). Lichens colonized the sand surfaces of young nonforested dune ridges but declined under developing forest canopy on dune ridges $225 \mathrm{yr}$ and older, whereas mosses colonized in the shade of juniper shrubs on young dune ridges and remained a minor component of the forest understory (Table 2).

Mixed pine forest consisting of white pine (Pinus strobus), red pine (Pinus resinosa), white spruce (Picea 

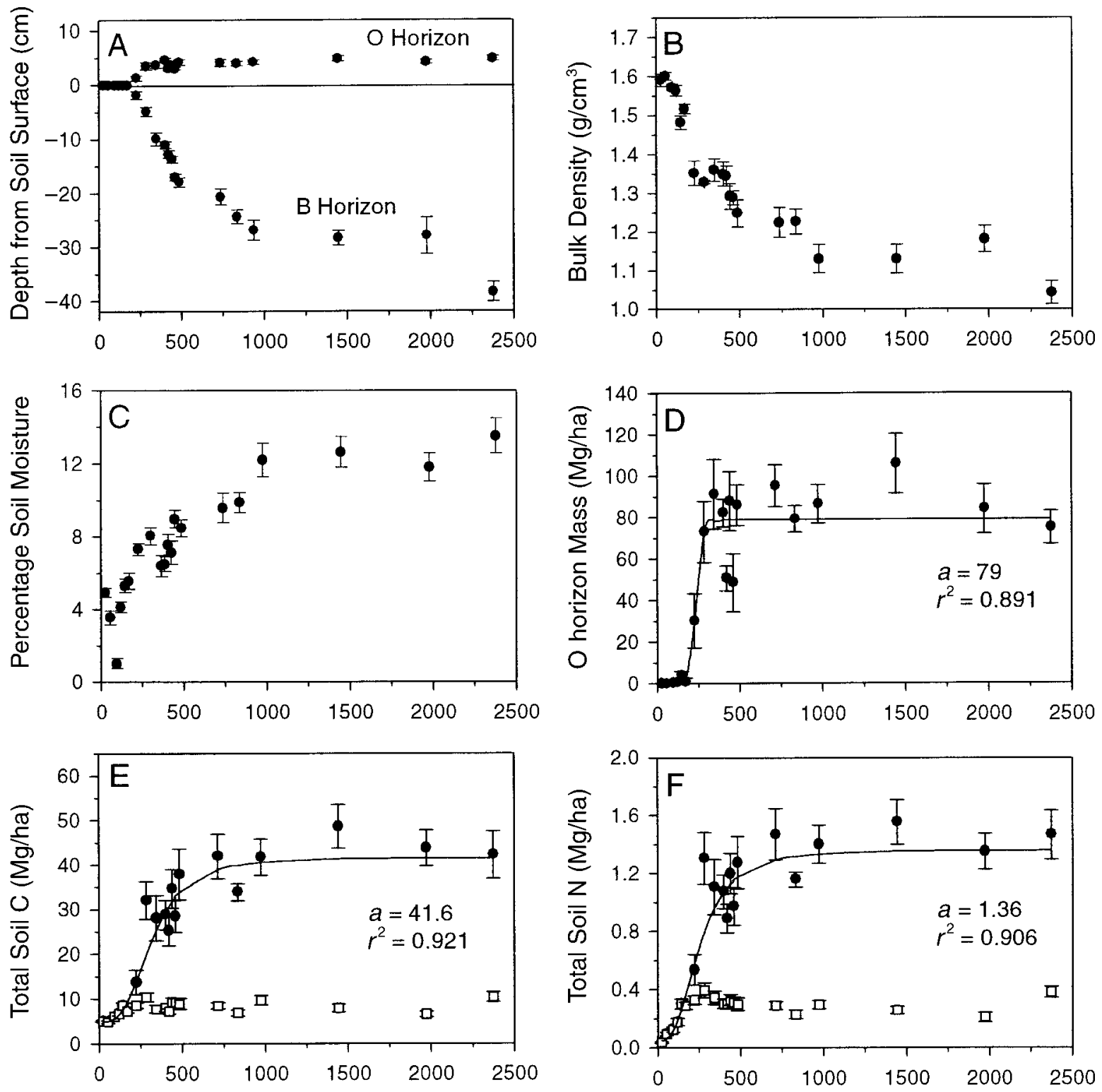

Dune Age (yr)

FIG. 8. Soil profile development (A) and changes in field bulk density (B), percentage moisture (C), O horizon mass (D), soil carbon (E), and soil nitrogen (F) during primary succession. Data are means ( \pm 1 SE, $n=12)$. The asymptote $(a)$ and coefficient of determination are given for the fitted model in D-F.

glauca), balsam fir (Abies balsamea), white cedar (Thuja occidentalis), and paper birch (Betula papyrifera) developed between 225 and 440 yr (Table 1). Although white pine, white spruce, white cedar, and tamarack (Larix laracina) colonized the margins along each of the nonforested interdunal swales (aged 25-175 yr), few tree seedlings established on the upland dune ridges until $145 \mathrm{yr}$. White pine dominated between 225 and $285 \mathrm{yr}$, but red pine became more abundant between 345 and 440 yr (Fig. 4A). Red maple (Acer rubrum) and red oak (Quercus rubra) entered the succession at
225 yr but did not become important components of the forest until $440 \mathrm{yr}$ (Fig. 4B). Eastern hemlock (Tsuga canadensis) was locally abundant on the 1445- and 1975-yr-old dune ridges (Fig. 4A), but beech (Fagus grandifolia) occurred only rarely as seedlings, and sugar maple (Acer saccharum) was not present in any of the survey plots. Pine stumps remaining from 19th century logging were found on ridges $400 \mathrm{yr}$ and older. Minimal biomass was removed from the 400-yr-old dune ridge, but biomass estimates of harvested pine trees varied around $20 \mathrm{Mg} / \mathrm{ha}$ on dune ridges 440- 
TABLE 1. Mean percent cover of vascular plant species on 14 dune ridges spanning the Wilderness State Park chronosequence $(n=4)$.

\begin{tabular}{|c|c|c|c|c|c|c|c|c|c|c|c|c|c|c|}
\hline \multirow[b]{4}{*}{ Species } & \multicolumn{14}{|c|}{ Dune number } \\
\hline & 1 & 2 & 3 & 5 & 6 & 7 & 8 & 9 & 11 & 13 & 24 & 36 & 54 & 72 \\
\hline & \multicolumn{14}{|c|}{ Dune age (yr) } \\
\hline & 25 & 55 & 95 & 145 & 175 & 225 & 285 & 345 & 400 & 440 & 835 & 1465 & 1975 & 2375 \\
\hline Lathyrus japonicus & 0.9 & 0.3 & & & & & & & & & & & & \\
\hline Salix exigua & 1.4 & 0.3 & $T$ & & & & & & & & & & & \\
\hline Ammophila breviligulata & 29.5 & 5.6 & 0.8 & & & & & & & & & & & \\
\hline Tanacetum huronese & 0.1 & 1.4 & $\ldots$ & 0.1 & & & & & & & & & & \\
\hline Oenothera biennis & $T$ & 0.1 & $T$ & $T$ & $T$ & & & & & & & & & \\
\hline Cirsium pitcheri & $T$ & 0.4 & 0.9 & $T$ & $T$ & & & & & & & & & \\
\hline Artemisia campestris & 0.2 & 1.0 & 0.8 & $T$ & 0.2 & & & & & & & & & \\
\hline Equisetum hyemale & 0.1 & $T$ & 0.3 & $T$ & $\cdots$ & $T$ & & & & & & & & \\
\hline Prunus pumila & 0.1 & 4.6 & 0.4 & 0.1 & $T$ & 0.1 & & & & & & & & \\
\hline Cornus stolinifera & & 0.1 & & & & & & & & & & & & \\
\hline Salix cordata & & 1.9 & 2.1 & & & & & & & & & & & \\
\hline Salix myricoides & & 2.5 & 0.3 & $T$ & & & & & & & & & & \\
\hline Asclepias syriaca & & $T$ & 0.6 & $\cdots$ & $T$ & & & & & & & & & \\
\hline Agropyron dasystachyum & & $T$ & $T$ & 0.1 & 0.1 & $T$ & & & & & & & & \\
\hline Solidago simplex & & $T$ & 0.2 & 0.1 & $T$ & $\cdots$ & $T$ & & & & & & & \\
\hline Lithospermum caroliniense & & $T$ & 0.1 & 0.3 & 0.3 & 0.1 & $T$ & 0.1 & & & & & & \\
\hline Toxicodendron radicans & & $T$ & $\ldots$ & $\cdots$ & $\cdots$ & 0.6 & 0.3 & 1.1 & 0.3 & $T$ & & & & \\
\hline Calamovilfa longifolia & & 7.4 & 9.6 & 1.3 & 1.3 & 0.6 & 3.5 & 5.5 & $\cdots$ & $T$ & & & & \\
\hline Arabis lyrata & & & $T$ & 0.1 & 0.2 & & & & & & & & & \\
\hline Schizachyrium scoparium & & & 1.9 & 5.5 & 15.3 & 0.6 & 0.1 & 0.1 & & & & & & \\
\hline Arctostaphylos uva-ursi & & & 10.0 & 13.0 & 13.3 & 0.2 & 0.4 & 0.5 & 0.4 & & & & & \\
\hline Smilacina stellata & & & $T$ & 0.1 & 0.2 & 0.7 & 0.8 & 0.4 & 0.2 & & & & & \\
\hline Shepherdia canadensis & & & & $T$ & & & & & & & & & & \\
\hline Festuca brachyphylla & & & & 0.1 & 0.1 & $\cdots$ & $T$ & & & & & & & \\
\hline Poa compressa & & & & 0.4 & 0.3 & 0.1 & 0.6 & & & & & & & \\
\hline Pyrola secunda & & & & 0.4 & $\cdots$ & 0.3 & $T$ & & & & & & & \\
\hline Hieracium sp. & & & & 0.1 & 0.2 & 0.2 & 0.2 & 1.0 & & & & & & \\
\hline Coreopsis lanceolata & & & & 0.3 & 0.1 & $T$ & 2.0 & 0.3 & & & & & & \\
\hline Achillea millefolium & & & & $T$ & $\cdots$ & $\cdots$ & $T$ & 0.2 & & & & & & \\
\hline Fragaria virginiana & & & & $T$ & $\cdots$ & $\cdots$ & 0.1 & 1.1 & & & & & & \\
\hline Juniperus horizontalis & & & & 1.1 & $\ldots$ & $T$ & 0.6 & 0.3 & & & & & & \\
\hline Juniperus communis & & & & 23.8 & 15.4 & 45.6 & 17.9 & 1.5 & $T$ & & & & & \\
\hline Campanula rotundifolia & & & & 0.1 & $T$ & $\ldots$ & $T$ & $T$ & $T$ & $T$ & & & & \\
\hline Chimaphila umbrellata & & & & 0.1 & $\ldots$ & 0.2 & $T$ & 0.3 & 0.1 & $T$ & $T$ & & & \\
\hline Spiranthes lacera & & & & $T$ & $\ldots$ & $\ldots$ & $\ldots$ & $T$ & $\ldots$ & $\ldots$ & $\cdots$ & $\ldots$ & $T$ & \\
\hline Picea glauca & & & & 8.0 & 1.2 & 8.0 & 14.0 & 8.0 & 11.9 & 2.0 & 12.6 & 0.1 & 4.9 & \\
\hline Thuja occidentalis & & & & 0.5 & $\cdots$ & $\cdots$ & 1.5 & $\cdots$ & $\cdots$ & $\cdots$ & 1.8 & 21.0 & 6.0 & 2.0 \\
\hline Melampyrum lineare & & & & 0.1 & 0.1 & 2.1 & 1.4 & 0.3 & 0.3 & 0.3 & 0.3 & $\ldots$ & $\ldots$ & 0.1 \\
\hline Betula papyrifera & & & & 0.1 & $\cdots$ & $T$ & $T$ & $T$ & 3.5 & 6.8 & 7.6 & 6.8 & 9.5 & 0.1 \\
\hline Pinus strobus & & & & 3.7 & 0.3 & 25.1 & 11.4 & 29.0 & 5.3 & 1.6 & 3.0 & 36.3 & 25.0 & 34.0 \\
\hline Pinus resinosa & & & & 1.6 & $T$ & 8.9 & 11.3 & 23.8 & 58.3 & 52.8 & 13.3 & 11.5 & 53.0 & 61.5 \\
\hline Zigadenus elegans & & & & & 0.1 & $T$ & & & & & & & & \\
\hline Carex eburnea & & & & & $T$ & $\cdots$ & $\cdots$ & $\cdots$ & $T$ & & & & & \\
\hline Rosa acicularis & & & & & $T$ & 0.1 & 0.2 & 0.2 & 0.1 & $\cdots$ & 0.1 & & & \\
\hline Prunus virginiana & & & & & $T$ & 1.7 & 15.3 & 11.0 & 4.1 & 0.1 & 0.8 & & & \\
\hline Commandra umbellata & & & & & $T$ & 0.1 & 0.1 & 0.2 & $\ldots$ & $T$ & 0.1 & & & \\
\hline Linnaea borealis & & & & & 0.1 & 2.4 & 3.4 & 7.2 & 2.4 & 0.1 & 0.1 & 0.4 & $T$ & \\
\hline Abies balsamea & & & & & 1.8 & 11.1 & 15.6 & 25.8 & 16.0 & 17.6 & 15.8 & 9.6 & 8.5 & 0.3 \\
\hline Aster sp. & & & & & $T$ & $T$ & 0.4 & 0.1 & & & & & & \\
\hline Pyrola asarifolia & & & & & & $T$ & & & & & & & & \\
\hline Diervilla lonicera & & & & & & 1.3 & 0.8 & & & & & & & \\
\hline Carex pensylvanica & & & & & & 4.3 & 7.3 & 0.1 & & & & & & \\
\hline Goodyera repens & & & & & & $T$ & $T$ & $T$ & $T$ & $\ldots$ & $T$ & & & \\
\hline Polygala paucifolia & & & & & & 0.8 & 0.5 & 0.2 & 0.2 & $\ldots$ & $\ldots$ & $T$ & & \\
\hline Cornus canadensis & & & & & & $T$ & 1.8 & 1.4 & 0.1 & $\cdots$ & 0.1 & $T$ & & \\
\hline Epigaea repens & & & & & & $T$ & $\cdots$ & $\cdots$ & 0.1 & 0.4 & 0.4 & 0.1 & $\cdots$ & 0.1 \\
\hline Trientalis borealis & & & & & & 0.6 & 0.9 & 0.5 & 0.3 & 0.3 & 0.7 & 0.6 & $T$ & 0.2 \\
\hline Maianthemum canadense & & & & & & 0.3 & 0.6 & 0.5 & 0.8 & 3.0 & 0.4 & 0.4 & 0.2 & 1.5 \\
\hline Vaccinium myrtilloides & & & & & & 0.1 & 1.1 & 0.5 & 5.7 & 6.2 & 12.8 & 3.7 & 2.0 & 1.8 \\
\hline Quercus rubra & & & & & & $T$ & $T$ & $T$ & 0.3 & 0.7 & 12.3 & $\cdots$ & $T$ & $T$ \\
\hline Acer rubrum & & & & & & $T$ & 0.1 & 1.9 & 3.8 & 17.2 & 31.8 & 21.5 & 12.6 & 5.1 \\
\hline Carex sp. & & & & & & $T$ & 0.1 & $\cdots$ & $\ldots$ & 0.5 & $T$ & $\ldots$ & $\ldots$ & 8.9 \\
\hline Elymus canadensis & & & & & & & 0.7 & & & & & & & \\
\hline Satureja vulgaris & & & & & & & 0.2 & & & & & & & \\
\hline Aralia nudicaulis & & & & & & & $T$ & 4.4 & 5.3 & 0.3 & 1.0 & 2.9 & $T$ & \\
\hline
\end{tabular}


TABle 1. Continued.

\begin{tabular}{|c|c|c|c|c|c|c|c|c|c|c|c|c|c|c|}
\hline \multirow[b]{3}{*}{ Species } & \multicolumn{14}{|c|}{ Dune number } \\
\hline & \multicolumn{13}{|c|}{ Dune age $(\mathrm{yr})$} & 72 \\
\hline & 25 & 55 & 95 & 145 & 175 & 225 & 285 & 345 & 400 & 440 & 835 & 1465 & 1975 & 2375 \\
\hline Oryzopsis asperifolia & & & & & & & $T$ & 1.6 & 0.4 & 0.1 & $\ldots$ & $\ldots$ & $\ldots$ & $T$ \\
\hline Cypripedium acaule & & & & & & & $T$ & 0.2 & 0.1 & $T$ & 0.3 & $\ldots$ & $T$ & 0.2 \\
\hline Lonicera dioica & & & & & & & & 0.3 & 0.5 & & & & & \\
\hline Lycopodium annotinum & & & & & & & & 0.7 & $T$ & $\ldots$ & $T$ & & & \\
\hline Deschampsia flexuosa & & & & & & & & 3.9 & 6.3 & 12.9 & 0.2 & & & \\
\hline Lycopodium complanatum & & & & & & & & & 0.4 & 0.1 & $T$ & & & \\
\hline Fagus grandifolia & & & & & & & & & $T$ & 0.1 & $\cdots$ & $T$ & & \\
\hline Gaultheria procumbens & & & & & & & & & $T$ & 5.1 & 3.9 & 1.6 & 1.8 & 0.4 \\
\hline Pteridium aquilinum & & & & & & & & & 19.1 & 24.6 & 23.3 & 12.9 & 8.8 & 25.3 \\
\hline Rubus idaeus & & & & & & & & & & 0.3 & & & & \\
\hline Equisetum variegatum & & & & & & & & & & 0.3 & $T$ & & & \\
\hline Clintonia borealis & & & & & & & & & & 0.1 & $\ldots$ & 0.2 & 0.2 & \\
\hline Vaccinium angustifolium & & & & & & & & & & 1.5 & $\ldots$ & $\ldots$ & $\ldots$ & 0.4 \\
\hline Gaylussacia baccata & & & & & & & & & & $T$ & 12.3 & 0.3 & 9.8 & 17.0 \\
\hline Monotropa uniflora & & & & & & & & & & & 0.1 & & & \\
\hline Populus tremuloides & & & & & & & & & & & 0.1 & $\ldots$ & $T$ & \\
\hline Lycopodium lucidulum & & & & & & & & & & & & 0.1 & & \\
\hline Pyrola elliptica & & & & & & & & & & & & $T$ & & \\
\hline Gaultheria hispidula & & & & & & & & & & & & 0.1 & $T$ & \\
\hline Tsuga canadensis & & & & & & & & & & & & 13.0 & 56.0 & 1.3 \\
\hline Amelanchier sp. & & & & & & & & & & & & & $T$ & \\
\hline Populus grandidentata & & & & & & & & & & & & & & $T$ \\
\hline
\end{tabular}

Note: Species are arranged in order of occurrence. $T$ indicates $<0.1 \%$ cover or $1-2$ small plants per $100-\mathrm{m}^{2}$ plot.

through 1975-yr-old (Fig. 4C). Dune ridges $\geq 2375$ yr, which are comprised of larger parabolic dunes, were logged much more intensively.

Plant species richness varied unimodally with increasing dune age (Fig. 5A). Total richness increased from a low of nine species at $25 \mathrm{yr}$ to a peak of 46 species at $285 \mathrm{yr}$, then decreased rapidly to 35 species at $400 \mathrm{yr}$, followed by a more gradual decline to a low of 20 species on the 2375-yr-old dune ridge. Opendune species richness peaked at $145 \mathrm{yr}$, then declined rapidly in developing forest between 175 and $440 \mathrm{yr}$. The number of canopy tree species increased through $345 \mathrm{yr}$, and then ranged between 8 and 11 species throughout established forest, whereas the number of forest understory species increased through $400 \mathrm{yr}$, but gradually declined after 835 yr. Shannon-Weiner diversity $\left(H^{\prime}\right)$ also varied unimodally with increasing dune age, peaking at $285 \mathrm{yr}$ (Table 3 ).

The number of colonizing species was highest in the period prior to forest establishment (25-225 yr), whereas species losses increased across the aggrading forest to a maximum at $400 \mathrm{yr}$ (Fig. 5B). Increased colonization on the 145- and 225-yr-old dune ridges was associated with initial establishment of numerous forest species. Average rates of species addition were highest between 95 and $145 \mathrm{yr}$, whereas average rates of species loss were highest between 345 and $440 \mathrm{yr}$ as earlysuccessional species were lost in the developing forest (Table 3). Species turnover was highest in the period prior to forest development (25-225 yr).

Colonization of young dune ridges by conifers was reflected in large increases in tree density, basal area, and aboveground biomass (Fig. 6). Tree density, total basal area, and aboveground biomass increased in a logistic manner to 1052 trees/ha, $38 \mathrm{~m}^{2} / \mathrm{ha}$, and 137 $\mathrm{Mg} / \mathrm{ha}$, respectively (Fig. 6A-C). Aboveground litter production increased to a peak of $\sim 350 \mathrm{~g} \cdot \mathrm{m}^{-2} \cdot \mathrm{yr}^{-1}$ at $440 \mathrm{yr}$ but varied between 175 and $350 \mathrm{~g} \cdot \mathrm{m}^{-2} \cdot \mathrm{yr}^{-1}$

TABLE 2. Mean percentage area of ground surface that was bare sand or was covered by lichen, moss, and plant and plant litter on dunes of different ages $(n=4)$.

\begin{tabular}{|c|c|c|c|c|c|c|c|c|c|c|c|c|c|c|}
\hline \multirow[b]{4}{*}{ Surface cover } & \multicolumn{14}{|c|}{ Dune number } \\
\hline & 1 & 2 & 3 & 5 & 6 & 7 & 8 & 9 & 11 & 13 & 24 & 36 & 54 & 72 \\
\hline & \multicolumn{14}{|c|}{ Dune age (yr) } \\
\hline & 25 & 55 & 95 & 145 & 175 & 225 & 285 & 345 & 400 & 440 & 835 & 1465 & 1975 & 2375 \\
\hline Bare sand & 67.8 & 74.3 & 72.2 & 16.3 & 33.8 & 1.0 & 0 & 0 & 0 & 0 & 0 & 0 & 0 & 0 \\
\hline Lichens & 0 & 0 & 0 & 5.4 & 9.0 & 0.6 & 2.6 & 4.3 & 3.4 & 0 & 2.5 & 0 & 0 & 0 \\
\hline Mosses & 0 & 0 & 0 & 1.3 & 2.0 & 22.5 & 8.2 & 20.3 & 19.6 & 19.1 & 2.3 & 8.3 & 0 & 1.0 \\
\hline Plant + Litter & 32.2 & 25.7 & 27.8 & 77.0 & 55.2 & 75.9 & 89.2 & 75.4 & 78.0 & 80.9 & 91.7 & 91.7 & 100 & 99.0 \\
\hline
\end{tabular}



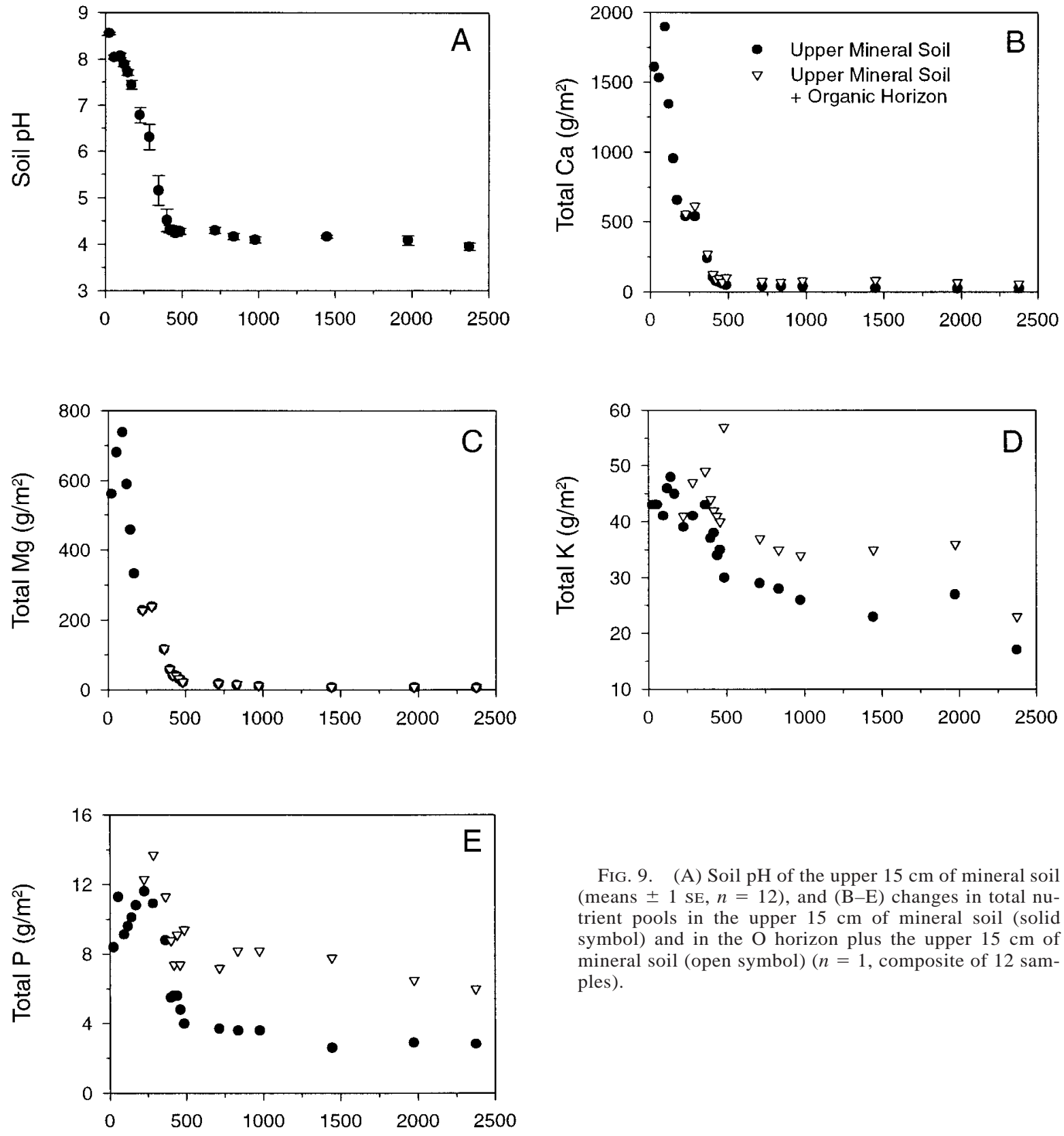

FIG. 9. (A) Soil $\mathrm{pH}$ of the upper $15 \mathrm{~cm}$ of mineral soil (means $\pm 1 \mathrm{SE}, n=12$ ), and (B-E) changes in total nutrient pools in the upper $15 \mathrm{~cm}$ of mineral soil (solid symbol) and in the $\mathrm{O}$ horizon plus the upper $15 \mathrm{~cm}$ of mineral soil (open symbol) ( $n=1$, composite of 12 samples).

TABLE 3. Successional changes in plant species diversity and in rates of colonization, extinction, and species turnover.

\begin{tabular}{|c|c|c|c|c|c|c|c|c|c|}
\hline \multirow[b]{3}{*}{ Variable } & \multicolumn{9}{|c|}{ Dune number } \\
\hline & 1 & 2 & 3 & 5 & $\begin{array}{c}6 \\
\text { Dune ag }\end{array}$ & 7 & 8 & 9 & 11 \\
\hline & 25 & 55 & 95 & 145 & 175 & 225 & 285 & 345 & 400 \\
\hline Total species richness $(S)$ & 9 & 18 & 18 & 34 & 31 & 41 & 46 & 41 & 35 \\
\hline Shannon Diversity $\left(H^{\prime}\right)$ & 0.41 & 1.99 & 1.77 & 1.93 & 1.75 & 2.00 & 2.62 & 2.42 & 2.14 \\
\hline Evenness $\left(H^{\prime} / \ln S\right)$ & 0.18 & 0.69 & 0.62 & 0.55 & 0.51 & 0.54 & 0.68 & 0.79 & 0.60 \\
\hline Average rate of species colonization (I/yr) & 0.36 & 0.30 & 0.10 & 0.48 & 0.27 & 0.10 & 0.08 & 0.05 & 0.07 \\
\hline Average rate of species extinction $(E / \mathrm{yr})$ & 0 & 0 & 0.05 & 0.06 & 0.10 & 0.10 & 0.08 & 0.12 & 0.15 \\
\hline Species turnover $(I+E) / S_{\mathrm{T}}$ & $\ldots$ & 0.50 & 0.36 & 0.56 & 0.26 & 0.31 & 0.17 & 0.21 & 0.29 \\
\hline
\end{tabular}




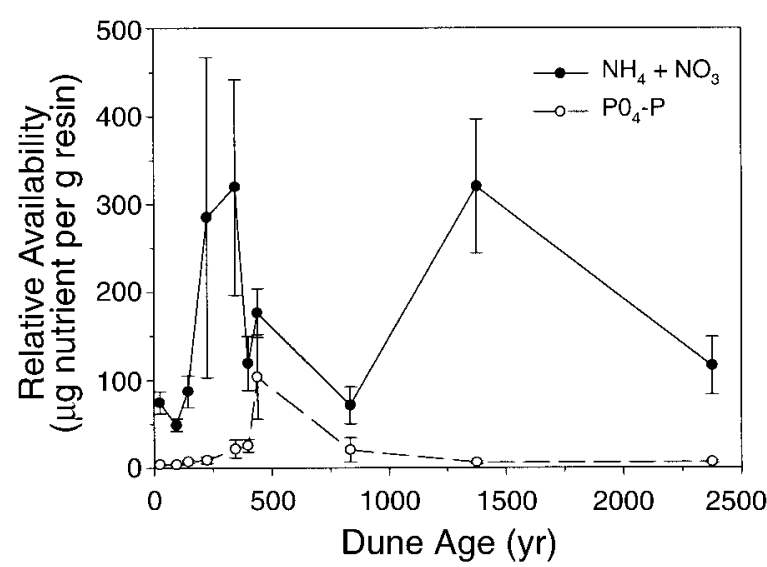

FIG. 10. Changes in the relative availability of nitrogen and phosphorus measured with ion-exchange resin. Data are means ( $\pm 1 \mathrm{sE}, n=8)$.

across the older dune ridges (Fig. 6D). Light penetration of the canopy decreased to $\sim 23 \%$ of full sunlight with forest development (Fig. 7).

\section{Soil properties}

Soil properties underwent rapid changes with colonization and growth of conifers. Increasing litter production led to accumulation of an $\mathrm{O}$ horizon, which reached a steady-state mean thickness of $4.1 \mathrm{~cm}$ (range $3-5 \mathrm{~cm}$ ) within $285 \mathrm{yr}$ of dune formation or $\sim 140 \mathrm{yr}$ after colonization by conifers (Fig. 8A). The illuvial B horizon began developing during forest aggradation and continually deepened with increasing dune age as $\mathrm{Fe}, \mathrm{Al}$, and organic matter were transported downward in the soil profile. Field bulk density of the top $15 \mathrm{~cm}$ of mineral soil decreased from $1.6 \mathrm{~g} / \mathrm{cm}^{3}$ in undeveloped soils to $\sim 1.15 \mathrm{~g} / \mathrm{cm}^{3}$ in forest soils (Fig. 8B) as organic matter was incorporated into the mineral soil, and as soil porosity increased because of repeated root growth and decay and tunneling activity of soil animals (Brimhall et al. 1991). Percentage moisture of the upper mineral soil at the time of soil sampling increased with increasing dune age (Fig. 8C).

$\mathrm{O}$ horizon mass, total soil $\mathrm{C}$, and total soil $\mathrm{N}$ each accumulated in a logistic manner, reaching steady-state levels by $440 \mathrm{yr}$. O horizon mass increased to $79 \mathrm{Mg}$ / ha (Fig. 8D), whereas soil $\mathrm{C}$ increased to $42 \mathrm{Mg} / \mathrm{ha}$

TABLE 3. Extended.

\begin{tabular}{ccccc}
\hline \hline \multicolumn{5}{c}{ Dune number } \\
\hline 13 & 24 & $\begin{array}{c}36 \\
\text { Dune age }\end{array}$ & 54 & 72 \\
\hline \multicolumn{5}{c}{140.075} \\
\hline 33 & 835 & 1465 & 1975 & 2375 \\
2.09 & 2.41 & 24 & 24 & 20 \\
0.60 & 0.70 & 0.68 & 2.08 & 1.76 \\
0.13 & 0.01 & 0.01 & 0.004 & 0.59 \\
0.13 & 0.01 & 0.01 & 0.01 & 0.02 \\
0.34 & 0.15 & 0.33 & 0.19 & 0.26 \\
\hline
\end{tabular}
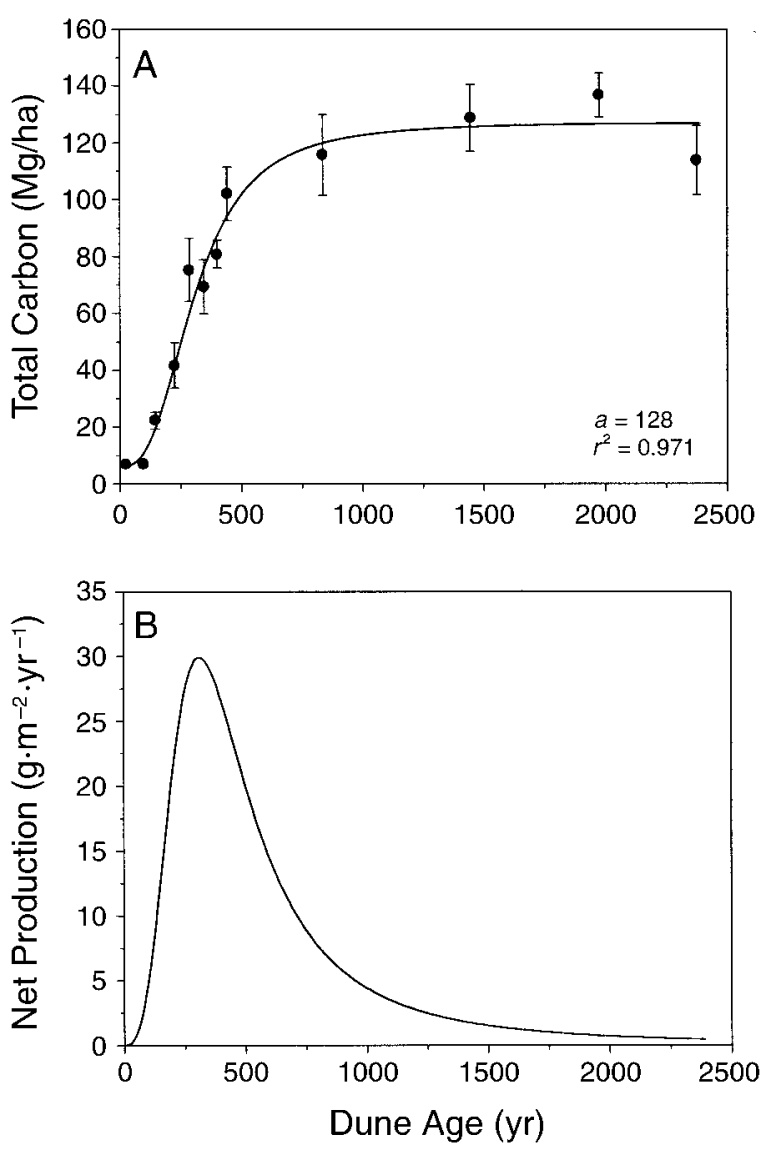

FIG. 11. (A) Accumulation of ecosystem carbon during primary succession and forest development. Data are means ( $\pm 1 \mathrm{SE}, n=4)$. The asymptote $(a)$ and the coefficient of determination $\left(r^{2}\right)$ are given for the fitted model. (B) Net ecosystem production is given as the derivative of the fitted logistic model.

(Fig. 8E), and soil $\mathrm{N}$ increased to $1.36 \mathrm{Mg} / \mathrm{ha}$ (Fig. 8F). Total $\mathrm{C}$ and $\mathrm{N}$ in the upper $15 \mathrm{~cm}$ of mineral soil accumulated to steady-state levels within $145 \mathrm{yr}$ of dune formation.

The $\mathrm{pH}$ of the upper $15 \mathrm{~cm}$ of mineral soil decreased rapidly from $\mathrm{pH} 8.5$ to $\mathrm{pH} 4.1$ during the establishment of conifers to $440 \mathrm{yr}$ (Fig. 9A). Soil acidification contributes to mineral weathering and mobilization of cationic nutrients and $\mathrm{P}$. $\mathrm{Ca}$ and $\mathrm{Mg}$ pools in the upper mineral soil decreased precipitously with increasing dune age, and neither element accumulated in the forest floor, indicating that these nutrients were leached below the upper $15 \mathrm{~cm}$ of mineral soil (Fig. 9B, C). K decreased less rapidly and did accumulate in the $\mathrm{O}$ horizon, indicating that plant uptake contributed to $\mathrm{K}$ removal from the mineral soil (Fig. 9D). P pools in the upper mineral soil were relatively constant through 345 yr but decreased precipitously between 345 and $485 \mathrm{yr}$ (Fig. 9E). Approximately 50\% of the $\mathrm{P}$ removed from the upper mineral soil was returned to the $\mathrm{O}$ horizon in aboveground litterfall, indicating an important role of plant uptake in depleting $\mathrm{P}$ from the mineral soil. 
TABLE 4. Regression analyses testing the influence of 19th century logging on diversity and ecosystem properties across dune ridges $\geq 400 \mathrm{yr}$ of age.

\begin{tabular}{lccrcr}
\hline \hline \multicolumn{1}{c}{ Dependent variable } & Coefficient & SE & $t$ & $P$ & $r^{2}$ \\
\hline Total species richness, $S$ & -0.097 & 0.035 & -2.78 & 0.01 & 0.26 \\
Understory species richness, Su & -0.057 & 0.027 & -2.10 & 0.05 & 0.17 \\
Aboveground biomass & 0.265 & 0.273 & 0.97 & 0.34 & 0.04 \\
O horizon mass & -0.009 & 0.020 & -0.44 & 0.66 & 0.01 \\
\hline
\end{tabular}
24).

Relative availabilities of $\mathrm{N}$ and $\mathrm{P}$ increased during the primary succession between 25 to $440 \mathrm{yr}$ (Fig. 10). The sum of relative $\mathrm{NH}_{4}-\mathrm{N}$ and $\mathrm{NO}_{3}-\mathrm{N}$ availability varied widely but approximately tripled between open dune ridges $($ mean $=70.2 \mu \mathrm{g}$ nutrient $/ \mathrm{g}$ resin) and forested dune ridges (mean $=201.0 \mu \mathrm{g}$ nutrient $/ \mathrm{g}$ resin), whereas relative $\mathrm{PO}_{4}-\mathrm{P}$ availability was less variable, increasing $\sim 15$ times between 25 and $440 \mathrm{yr}$, but then decreasing across older dune ridges.

\section{Long-term effects of 19th century logging}

Linear regression analyses showed that estimated aboveground biomass of pine trees harvested during 19 th century logging was not a good predictor of current aboveground and detrital biomass (Table 4). However, biomass of harvested pine trees was a statistically significant predictor of both total species richness and forest understory species richness, although accounting for only small proportions of the total variation in these variables.

\section{Net ecosystem production}

The logistic model provided a good fit to carbon accumulation in soils and in biomass across the dune chronosequence (Fig. 11A). Ecosystem carbon accumulated to a steady-state level of $\sim 128 \mathrm{Mg} \mathrm{C} / \mathrm{ha}^{1}$ by $835 \mathrm{yr}$, whereas net ecosystem production increased rapidly during the primary succession to a maximum of $\sim 30 \mathrm{~g} \mathrm{C} \cdot \mathrm{m}^{-2} \cdot \mathrm{yr}^{-1}$ in developing forest and then decreased to zero net ecosystem production in established forest (Fig. 11B). The mean annual rate of ecosystem carbon accumulation was $23.2 \mathrm{~g} / \mathrm{m}^{2}$ and the mean annual rate of ecosystem nitrogen accumulation was 0.38 $\mathrm{g} / \mathrm{m}^{2}$ over $440 \mathrm{yr}$ of primary succession and forest aggradation (Table 5). Mean annual rates of carbon and

TABLE 5. Total accumulation and average annual rates of carbon and nitrogen accumulation in living biomass (aboveground + belowground) and in soils (O horizon + upper $15 \mathrm{~cm}$ of mineral soil) through $440 \mathrm{yr}$ of primary succession.

\begin{tabular}{lccccc}
\hline \hline & \multicolumn{2}{c}{$\begin{array}{c}\text { Total quantity } \\
(\mathrm{Mg} / \mathrm{ha})\end{array}$} & & \multicolumn{2}{c}{$\begin{array}{c}\text { Rate of accumula- } \\
\text { tion }\left(\mathrm{g} \cdot \mathrm{m}^{-2} \cdot \mathrm{yr}^{-1}\right)\end{array}$} \\
\cline { 2 - 3 } \cline { 6 - 6 } \multicolumn{1}{c}{ Pool } & Carbon & Nitrogen & & Carbon & Nitrogen \\
\hline Biomass & 67.4 & 0.47 & & 21.3 & 0.11 \\
Soil & 34.7 & 1.20 & & 7.9 & 0.27 \\
Total ecosystem & 102.1 & 1.67 & & 23.2 & 0.38 \\
\hline
\end{tabular}

nitrogen accumulation in biomass were 21.3 and 0.11 $\mathrm{g} / \mathrm{m}^{2}$, respectively, whereas mean annual rates of carbon and nitrogen accumulation in surface soils (i.e., $\mathrm{O}$ horizon and upper $15 \mathrm{~cm}$ of mineral soil) were $7.9 \mathrm{~g} /$ $\mathrm{m}^{2}$ and $0.27 \mathrm{~g} / \mathrm{m}^{2}$, respectively (Table 5).

\section{Physical environment}

Potential physical stresses related to sand movement, wind, and evaporation decreased with distance from the lake shore and with increasing dune age. Between 1990 and 1996, the first dune ridge accumulated sand consistently but the second through fifth dune ridges (55-145 yr) experienced little sand movement. Mean annual sand accretion on the first dune ridge averaged $3.0 \mathrm{~cm}( \pm 1.8)$, whereas sand accretion on the second and third ridges averaged $0.1 \mathrm{~cm}( \pm 0.1)$, and on the fourth and fifth ridges, $-0.02 \mathrm{~cm}( \pm 0.1)$. Wind velocities $1.5 \mathrm{~m}$ above the dune surface of upland ridges decreased with distance from the shore, and the third interdunal swale ( $95 \mathrm{yr}$ ) had lower wind velocities than nonforested upland dune ridges (Table 6A). Wind velocities were negligible near the dune surface except on the fifth dune ridge. Evaporation was greater on nonforested dune ridges and in the nonforested swale than on forested dune ridges (Table 6B). Rates of soil drying depended on depth and location (Table 6C). Following heavy rains, surface soils $(0-5 \mathrm{~cm}$ depth) of nonforested dune ridges dried more rapidly and more thoroughly than deeper soils (10-15 cm depth), and more thoroughly than forest soils. Soils of the nonforested interdunal swale remained at their initial moisture levels at both depths.

\section{Diversity-environment relations}

Relations between species diversity and environmental variables were generally unimodal (Fig. 12). The exception is the relationship between species richness and soil $\mathrm{P}$, which was best modeled with two linear equations (Fig. 12F). Species richness increased with increasing soil $\mathrm{P}$ between 25 and $285 \mathrm{yr}$, but then decreased with decreasing soil $\mathrm{P}$ from $345 \mathrm{yr}$ on.

\section{DISCUSSION}

Frequent and continuing formation of shore-parallel dune ridges at WSP resulted in clear patterns of succession and forest ecosystem development. Patterns of species turnover and community convergence as well 
TABLE 6. Changes in physical environment across selected dunes measured in 1995.

\begin{tabular}{cccc}
\hline \hline A) Wind velocity (m/s) on 5 June (ANOVA df $=3,8)$ & & \\
Location & $1.5 \mathrm{~m}$ height & Dune surface & Reduction \\
\hline Dune no. 1 (25 yr), open & $6.6(0.1)$ & $0.2(0.1)$ & $1.0(0.02)$ \\
Swale no. 3 (95 yr), open & $2.3(0.7)$ & $0.2(0.2)$ & $0.9(0.1)$ \\
Dune no. 5 (145 yr), open & $3.6(0.4)$ & $1.5(0.1)$ & $0.6(0.03)$ \\
Dune no. 8 (285 yr), forest & $1.4(0.2)$ & $0.2(0.1)$ & $0.8(0.1)$ \\
ANOVA & $F=29.6$ & $F=15.5$ & $F=11.1$ \\
& $P \leq 0.001$ & $P \leq 0.001$ & $P \leq 0.01$
\end{tabular}

B) Percentage water evaporated on 5 June (ANOVA df $=3,8$ )

\begin{tabular}{ccc} 
Location & 22 May & 5 June \\
\hline Dune no. 1 $(25 \mathrm{yr})$, open & $15.0(0.6)$ & $49.0(1.0)$ \\
Swale no. 3 $(95 \mathrm{yr})$, open & $12.7(0.3)$ & $40.7(4.1)$ \\
Dune no. 5 (145 yr), open & $13.7(0.3)$ & $47.7(2.8)$ \\
Dune no. 8 $(285 \mathrm{yr})$, forest & $2.7(0.9)$ & $14.3(0.9)$ \\
ANOVA & $F=95.3$ & $F=44.0$ \\
& $P \leq 0.001$ & $P \leq 0.001$
\end{tabular}

C) Percentage moisture at $0-5 \mathrm{~cm}$ depth for $3 \mathrm{~d}$ following a heavy rainfall (ANOVA $\mathrm{df}=3,16$ )

\begin{tabular}{ccrrr} 
Location & \multicolumn{1}{c}{ Initial } & \multicolumn{1}{c}{ Day 1 } & \multicolumn{1}{c}{ Day 2 } & \multicolumn{1}{c}{ Day 3 } \\
\hline Dune no. 1 (25 yr), open & $6.4(0.6)$ & $4.0(0.7)$ & $2.0(0.3)$ & $1.3(0.5)$ \\
Swale no. 3 (95 yr), open & $16.0(2.1)$ & $12.9(4.2)$ & $14.6(3.1)$ & $18.5(4.3)$ \\
Dune no. 5 (145 yr), open & $4.5(0.4)$ & $4.0(0.4)$ & $2.7(0.4)$ & $1.5(0.6)$ \\
Dune no. 8 (285 yr), forest & $10.1(1.1)$ & $10.0(2.5)$ & $7.0(1.6)$ & $6.6(0.8)$ \\
ANOVA & $F=16.6$ & $F=3.3$ & $F=10.6$ & $F=13.0$ \\
& $P \leq 0.001$ & $P \leq 0.048$ & $P \leq 0.001$ & $P \leq 0.001$
\end{tabular}

D) Percentage moisture at $10-15 \mathrm{~cm}$ depth for $3 \mathrm{~d}$ following a heavy rainfall (ANOVA $\mathrm{df}=3,16$ )

\begin{tabular}{crrrr} 
Location & \multicolumn{1}{c}{ Initial } & Day 1 & Day 2 & Day 3 \\
\hline Dune no. 1 (25 yr), open & $5.7(1.4)$ & $4.8(0.8)$ & $3.5(0.3)$ & $3.5(0.3)$ \\
Swale no. 3 $(95 \mathrm{yr})$, open & $16.3(1.9)$ & $19.3(2.0)$ & $16.2(1.4)$ & $17.7(1.7)$ \\
Dune no. 5 $(145 \mathrm{yr})$, open & $4.3(0.3)$ & $3.7(0.5)$ & $4.3(0.8)$ & $4.0(0.8)$ \\
Dune no. 8 $(285 \mathrm{yr})$, forest & $6.2(1.4)$ & $4.3(0.4)$ & $3.5(0.6)$ & $4.0(1.1)$ \\
ANOVA & $F=16.1$ & $F=44.0$ & $F=48.5$ & $F=37.9$ \\
& $P \leq 0.001$ & $P \leq 0.001$ & $P \leq 0.001$ & $P \leq 0.001$ \\
\hline
\end{tabular}

Note: Data are means ( $\pm 1 \mathrm{SE})$.

as gradational changes in ecosystem properties indicate a primary succession across the youngest $440 \mathrm{yr}$ (first 13 ridges) of the dune chronosequence. The succession is similar to the classic dune succession described at the Indiana Dunes (Cowles 1899, Olson 1958b) in which early successional "dune-building" species are replaced by evergreen shrubs and bunchgrass, that, in turn, are replaced by mixed pine-oak forest.

\section{Community development}

Although species turnover occurs across the entire 2375-yr soil chronosequence, only compositional changes over a few hundred years are likely to represent the pathway of primary succession. Disturbance and secondary succession eventually alter the composition and age structure of forest communities, creating a mosaic of different-aged patches (Loucks 1970, Bormann and Likens 1979, Shugart 1984). Changes in relative abundances of species across the initial $400 \mathrm{yr}$ of the sequence indicate that compositional changes represent the pathway of primary succession at individual sites within the chronosequence. Subsequent changes on older ridges suggest that selective logging of large pine trees during the late 19th century altered forest composition. After $400 \mathrm{yr}$, decreased abundance of white pine and red pine, and increased abundances of red maple and red oak are probably associated with logging disturbance rather than with primary succession. Logging contributed to conversion of mixed pine-oak forest to oak woodland at the Indiana Dunes (Cowles 1899 , Olson 1958b), and oak frequently replaces pine following extensive logging and fire (Crow 1988, Abrams 1992). Based on the presence of shade-tolerant conifers such as balsam fir and northern white cedar, the presettlement forest was probably mixed white pine-red pine forest characteristic of infrequent fire (i.e., $>300$ yr return period; Heinselman 1981) rather than pine-oak forest.

Community convergence in species composition is consistent with classical succession theory (Clements 1916), but contrasts with empirical studies documenting divergence and multiple pathways of succession (e.g., Olson 1958b, Matthews 1979, Christensen and Peet 1984, McCune and Allen 1984, Fastie 1995). The question is, what constrains community divergence at WSP? At the Indiana Dunes, Olson (1958b) described 

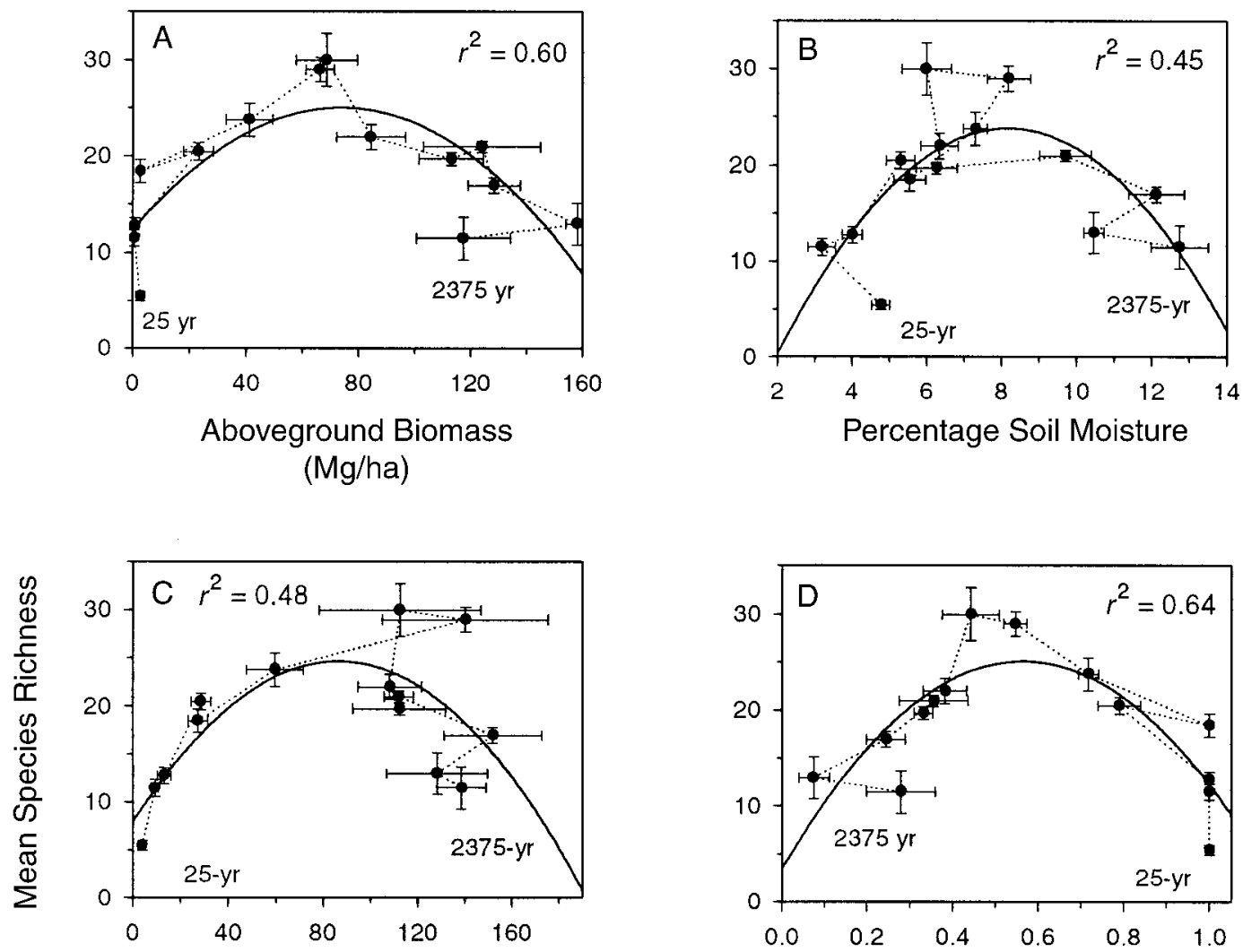

Total Soil N $\left(\mathrm{g} / \mathrm{m}^{2}\right)$
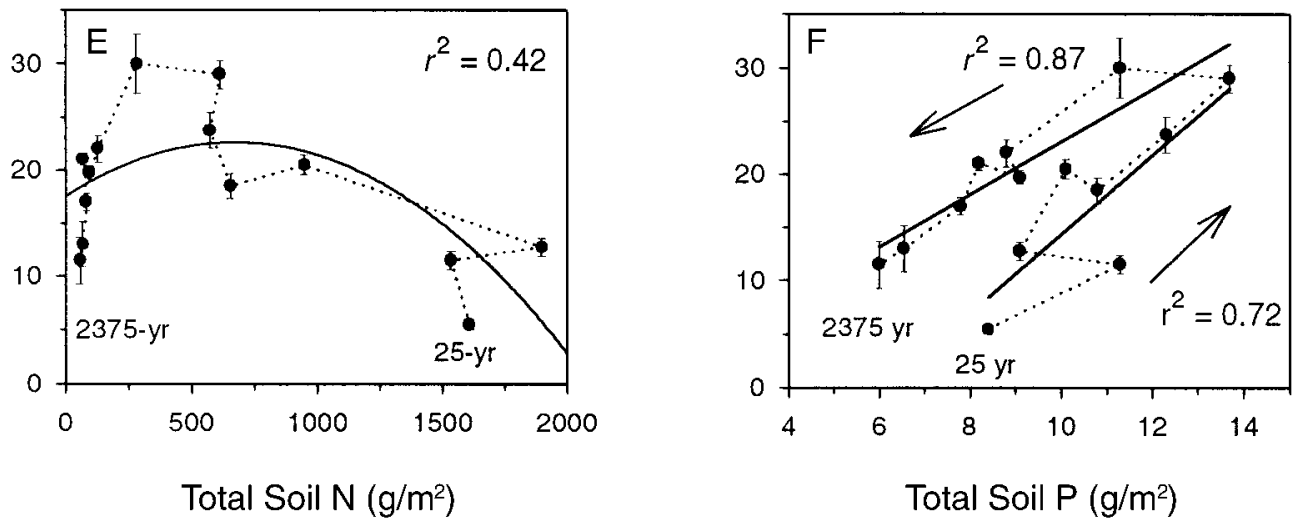

FIG. 12. Diversity-productivity relations. Mean species richness as a function of aboveground biomass (A), percentage soil moisture (B), soil nitrogen (C), light penetration of the canopy (D), soil calcium (E), and soil phosphorus (F). Relationships are modeled with first- or second-order linear regression equations. Trajectories from the 25-yr-old dune ridge to the 2375 yr-old dune ridge are shown by the dotted lines. Data are means $( \pm 1 \mathrm{SE}, n=4)$.

alternative successions across diverse sites including fossil beaches, shore-parallel dune ridges, and parabolic dunes. However, at WSP, I measured vegetation and soil properties only on stable, shore-parallel dune ridges of similar topography and parent materials. Site differences in topography and depth to the water table at the Indiana Dunes provided a more variable geomorphic setting, potentially less restrictive to a variety of successional pathways. Also, the Indiana Dunes were repeatedly disturbed by logging and fire in the century preceding Olson's study (Cowles 1899, Olson $1958 b)$. At WSP, much of the dune chronosequence 
experienced relatively little human-related disturbance apart from selective pine logging during the 19th century (W. Smith, unpublished manuscript).

A frequent cause of compositional divergence during primary succession is variation in seed rain (e.g., van Dorp et al. 1985, McClanahan 1986, Wood and del Moral 1987, Whittaker et al. 1989, Fastie 1995). However, at WSP, the direction and distance to seed sources may have been relatively constant throughout the development of the chronosequence. Seeds of many species wash up onto the beach and germinate along the strandline, but only those capable of withstanding extreme physical stresses associated with frequent sediment deposition and erosion survive on the active beach and first dune ridge. Seeds of later successional species dispersing to young dune ridges must therefore originate on older dune ridges. The distance between newly formed dune ridges and seed sources might remain relatively constant because the dune ridges are narrow and the generation time of conifers (20-25 yr) is less than the average return period of dune formation (33.5 yr). Therefore, colonization of late-successional species might have kept pace with dune formation. In contrast, multiple pathways of succession at Glacier Bay, Alaska, resulted from the inability of late-successional spruce and hemlock to disperse as rapidly as the glacier retreated (Fastie 1995).

\section{Successional changes in species diversity}

Changes in plant species diversity provide information about environmental constraints that potentially influence the primary succession and regulate species diversity. Increasing species richness between 25 and $285 \mathrm{yr}$ may be related to increasing soil organic matter and related increases in soil moisture, soil $\mathrm{N}$, and soil $\mathrm{P}$, as well as to decreasing physical stress as wind velocities and sand movement diminish, or to cumulative opportunities for chance colonization. The species richness maximum in developing forest occurs after most forest species have successfully colonized and while many open-dune species are still present. The rapid decrease in species richness between 285 and $440 \mathrm{yr}$ is associated with the loss of open-dune species in developing forest, and the long-term decline in species richness between 440 and $2375 \mathrm{yr}$ is associated with the more gradual loss of forest understory herbs. Local species extinction may be caused by competition for light or soil nutrients, by regeneration limitation, or by the logging disturbance. Logging operations might have indirectly caused local extinction by changing environmental conditions that influence the long-term survival and recruitment of understory populations (Meier et al. 1995). Understory herbs are typically long-lived and have low rates of population growth (Bierzychudek 1982) and may therefore be especially vulnerable to local extinction. It is not uncommon for understory diversity to be depressed for several decades after logging (Brewer 1980, Peterken and Game
1984, Duffy and Meier 1992). Although not compelling, significant regression relationships between estimated aboveground biomass of harvested pine trees and both total species richness and understory species richness on dune ridges $\geq 400$ yr old suggest lasting negative effects of 19th century logging on plant diversity.

Two general trends of successional change in species diversity have been observed in forests. Diversity may increase in a logistic manner toward a steady-state asymptote in mature forest (Odum 1969) or diversity may increase to a peak in successional forest and later decline to an intermediate steady state in mature forest (Margalef 1963). Logistic or monotonic increase to a presumed steady state has been described for southeastern deciduous forests (Monk 1967), tropical forests (Brunig 1973), succession following glacial retreat (Reiners et al. 1971), forest succession on extreme sites in the Colorado front range (Peet 1978), and succession following volcanic activity (Rejmanek et al. 1982, Whittaker et al. 1989, Aplet and Vitousek 1994). However, a unimodal peak has been reported more frequently. Auclair and Goff (1971) summarized diversity relations for forests in the western Great Lakes region and found a unimodal peak for a variety of forest types, and similar results were found for oak (Loucks 1970), boreal (Shafi and Yarranton 1973), floodplain (Johnson et al. 1976), northern hardwood (Bormann and Likens 1979), mixed pine/hardwood (Hibbs 1983), and western coniferous (Schoonmaker and McKee 1988) forests.

Changes in diversity at WSP show that whichever successional trend in diversity is observed may depend on whether both canopy and understory species are considered and on the length of time over which succession was observed. If only tree species were considered at WSP, diversity would have increased to a steady state rather than peak and later decline, and if only the first $350 \mathrm{yr}$ of succession were observed, diversity would have increased monotonically (see Fig. $5 \mathrm{~A}$ ). Of the studies describing logistic or monotonic increase in diversity, only Reiners et al. (1971) and Whittaker et al. (1989) reported changes in canopy and understory diversity for a succession lasting more than a few decades.

\section{Forest ecosystem development}

The close fit of the logistic growth model to accumulating tree density, basal area, and aboveground biomass indicates that rates of tree colonization during the primary succession are low relative to rates of recruitment following disturbance in many secondary forest successions (Peet 1992). Where seed arrival and seedling establishment are not limiting, a thinning phase often occurs that reduces tree density and stand biomass below peak levels as trees reach adult size (Loucks 1970, Bormann and Likens 1979). That is, more seedlings establish following the disturbance than can oc- 
cupy the site as mature trees. The lack of a thinning phase at WSP indicates that colonization rates are low enough such that tree densities in developing forest are maintained (Peet 1992). Similar patterns of monotonic increase to presumed steady-state biomass have been reported for both primary (e.g., Olson 1958b, Reiners et al. 1971, Bormann and Sidle 1990, Drake and Mueller-Dombois 1993), and secondary forest successions (e.g., Forcella and Weaver 1977, Sprugel 1984, Harcombe et al. 1990).

Changes in soil properties across the dune chronosequence illustrate classic patterns of soil organic matter accumulation and soil podzolization (e.g., Franzmeier and Whiteside 1963, Stevens and Walker 1970). Within $440 \mathrm{yr}$ of dune formation, soil organic matter accumulates to steady-state levels, carbonate minerals weather and large quantities of calcium and magnesium are leached, the $\mathrm{pH}$ of the upper mineral soil decreases from 8.5 to 4.3 , and the illuvial B soil horizon begins to form. Production of organic and carbonic acids associated with decomposition of coniferous litter accelerates mineral weathering and release of cationic nutrients, $\mathrm{P}$, and trace metals. Fe and Al compounds are transported downward in the soil profile until they precipitate out of solution to form the incipient $\mathrm{B}$ horizon. Plant nutrients are either leached below the rooting zone or are taken up by plants and soil microbes. Contrary to $\mathrm{Ca}$ and $\mathrm{Mg}$, significant proportions of the $\mathrm{K}$ and $\mathrm{P}$ originally present in the upper mineral soil accumulate in the $\mathrm{O}$ horizon. This tighter cycling suggests that $\mathrm{K}$ and $\mathrm{P}$ limit plant growth, whereas $\mathrm{Ca}$ and $\mathrm{Mg}$ do not. $\mathrm{K}$ has been shown to limit plant growth in sandy soils supporting red pine forest (Stone and Kszystyniak 1977), and a central role has been suggested for $\mathrm{P}$ in controlling soil organic matter accumulation and nutrient cycling (McGill and Cole 1981, Tate and Salcedo 1988) as well as primary production on older soils (Vitousek et al. 1993, Herbert and Fownes 1995). P may also indirectly control primary production by influencing $\mathrm{N}$ fixation (Vitousek and Howarth 1991, Chapin 1993), N mineralization rates (Cornish and Raison 1977), mineral N uptake (Cole and Heil 1981), and nitrification rates (Pastor et al. 1984).

The pattern of exponential decrease in soil $\mathrm{P}$ is consistent with the model of Walker and Syers (1976) in which P released from primary apatite minerals is taken up by plants or is transformed into secondary iron and aluminum phosphates. In alkaline soils, $\mathrm{P}$ may also be immobilized by Ca (Lajtha and Schlesinger 1988). This appears to be the case during primary succession at WSP. $\mathrm{P}$ pools in the upper mineral soil remain relatively constant until most of the $\mathrm{Ca}$ has been leached, after which, it is mobilized and pools in the upper mineral soil decrease exponentially to an asymptote associated with occluded $\mathrm{P}$ and weathering-resistant minerals (Lichter 1998).

Unlike primary successions following glacial retreat (Jacobson and Birks 1980, Chapin et al. 1994), sym- biotic $\mathrm{N}$ fixation does not contribute significantly to the aggrading forest ecosystem. The only $\mathrm{N}$-fixing species that occurs on the upland dune ridges is beach pea (Lathyrus japonicus), and it was sparsely distributed on only the first and second dune ridges. Three $\mathrm{N}$-fixing species inhabit the interdunal swales (sweet gale Myrica gale, speckled alder Alnus incana, and buffalo-berry Shepherdia canadensis); however, litter inputs from these species to the upland dune ridges are negligible. $\mathrm{N}$ accumulation must therefore depend on gradual sequestration of atmospheric inputs as suggested by Olson (1958a) for the Indiana Dunes. To assess this hypothesis, I compared the mean annual rate of $\mathrm{N}$ accumulation during ecosystem aggradation with historical rates of atmospheric $\mathrm{N}$ deposition. The mean annual rate of $\mathrm{N}$ accumulation was $0.38 \mathrm{~g} / \mathrm{m}^{2}$ over the past 440 yr (Table 5), whereas atmospheric $\mathrm{N}$ deposition measured at the University of Michigan Biological Station, which is located $26 \mathrm{~km}$ to the southeast, has averaged $0.51 \mathrm{~g} \cdot \mathrm{m}^{-2} \cdot \mathrm{yr}^{-1}( \pm 0.09)$ between 1980 and 1995 (National Atmospheric Deposition Program 1994). Although rates of atmospheric $\mathrm{N}$ deposition were lower prior to the onset of acid rain during this century, the approximate match between estimated rates of $\mathrm{N}$ accumulation and historical rates of $\mathrm{N}$ deposition does not support a conclusion that symbiotic $\mathrm{N}$ fixation contributes significantly to ecosystem aggradation. This result is consistent with Walker's (1993) conclusions that symbiotic N-fixers are usually present in primary successions but are not usually a dominant component, and thus do not necessarily contribute large quantities of $\mathrm{N}$ to ecosystem development.

\section{Net ecosystem production}

The close fit of the logistic model to the pattern of ecosystem $\mathrm{C}$ accumulation is consistent with conceptual models of ecosystem development (i.e., Vitousek and Reiners 1975, Gorham et al. 1979). As plants colonize young dune ridges, a larger proportion of nutrient inputs from the atmosphere are sequestered in the accumulating biomass and soil organic matter, resulting in greater rates of nutrient cycling and primary production. With accelerated rates of nutrient cycling and establishment of larger species, net ecosystem production increases to a peak in developing forest. As trees mature, increasing respiration costs relative to production (Kira and Shidei 1967, Odum 1969), tree senescence and declining vigor (Kira and Shidei 1967), or nutrient limitation (Sprugel 1985) inhibit further biomass accumulation and cause net ecosystem production to decline to zero as ecosystem carbon reaches an asymptote.

My estimates of total ecosystem C approximate those of Grigal and Ohmann (1992) for red pine forests in the Great Lakes region (i.e., 128 vs. $169 \mathrm{Mg} / \mathrm{ha}^{1}$ ), but my estimate of net ecosystem production is an order of magnitude lower than estimates for secondary forest successions (e.g., Marks 1974, Whittaker et al. 1974, 
Sprugel 1984, Pearson et al. 1987, Schiffman and Johnson 1989). This difference is related to delayed colonization and growth of trees during the primary succession. During many secondary forest successions, prior establishment of understory saplings and substantial seed rain may promote rapid forest recovery and high rates of net ecosystem production during the first few decades after the disturbance.

\section{Environmental change and species turnover}

There is general consensus that plant succession is caused by differential dispersal, survival, growth, and reproduction of species within a changing environment (e.g., Drury and Nisbet 1973, Peet and Christiansen 1980, Pickett et al. 1987, Walker and Chapin 1987, Tilman 1990). The numerous environmental changes at WSP indicate that the dune chronosequence represents a complex gradient along which changing environmental constraints differentially affect plant species depending on their life history traits and their colonization and competitive abilities. As the environment changes, different plant traits become favored and previously dominant species are competitively displaced by those possessing the favored traits. Potential environmental constraints during early succession include physical stresses related to sand movement, nutrient stress/competition, and colonization limitation, whereas potential constraints during late succession include competition for light, competition for soil nutrients, and regeneration limitation.

Physical stresses related to sand movement distinguish dune succession from other primary successions. High rates of sand accretion prevent most species from colonizing the active beach and first dune ridge. Seeds can be buried too deeply for seedling emergence (Weller 1989, Zhang and Maun 1990), or seedlings that do establish may be unable to outgrow cumulative sand accretion over several seasons (Harris and Davy 1987, Sykes and Wilson 1990, Maun 1996). Species that inhabit active dunes often have special adaptations that allow them to persist under substantial amounts of sand burial. For example, beach grass has vertical rhizomes and adventitious roots that allow it to outgrow sand accretion and regrow roots near the dune surface (Disraeli 1984, Maun and Lapierre 1984). Many dunebuilding species are clonal and colonize the beach from fragments of rhizome or stolen that wash ashore (Davy and Figueroa 1993), thereby avoiding colonization constraints associated with recruitment from seed.

Increasing nutrient availability during soil development is the proposed mechanism in the classic "soildriven" hypotheses of primary succession (Clements 1916, Connell and Slatyer 1977, Tilman 1985). These hypotheses assert that accumulating soil organic matter associated with early-successional species increases the availability of soil nutrients and thereby facilitates the establishment of larger, competitively superior species. At WSP, increasing availability of both $\mathrm{N}$ and $\mathrm{P}$ during the primary succession is consistent with this hypothesis. $\mathrm{N}$ availability increases as atmospheric inputs are captured by plants during succession and are recycled during organic matter decomposition. $\mathrm{P}$ availability increases as $\mathrm{Ca}$-bound phosphates are released and $\mathrm{Ca}$ is leached. Both $\mathrm{N}$ and $\mathrm{P}$ may limit plant growth during primary succession despite considerable quantities of $\mathrm{P}$ in the unweathered parent material (Raich et al. 1996).

Alternatively, colonization constraints associated with stochastic environmental and biotic conditions may delay colonization of late successional species. Chance seed arrival (McClanahan 1986, Walker et al. 1986, Wood and del Moral 1987, Whittaker et al. 1989), seed and seedling desiccation that depends on stochastic weather conditions (Wood and del Moral 1987, Wood and Morris 1990), and seed predation that depends on fluctuating rodent populations (De Steven 1991a, Gill and Marks 1991, Ostfeld et al. 1997) may be important mechanisms of colonization limitation. Other potential causes of colonization limitation are lack of mycorrhizal symbionts (Allen and Allen 1988) and herbivory (Ross et al. 1970, De Steven 1991b).

Pioneer trees usually colonize open dune ridges along the margins of interdunal swales where the proximity of the water table may alleviate seed and seedling desiccation and where dense herbaceous vegetation may prevent seed predators from finding seeds. These trees may subsequently facilitate colonization of the upland dune ridges by providing shade and litter (Kellman and Kading 1992). Accumulating soil organic matter under pioneer trees improves both the nutrient content and the moisture-holding capacity of the soil (Fig. 8C; see also Robertson and Vitousek 1981). Pioneer trees also provide perches for birds, which disperse seeds of many understory species (McDonnell and Stiles 1983). On these dunes, it is not uncommon to find a few understory species such as pipsissewa (Chimaphila umbellata), wild lily-of-the-valley (Maianthemum canadensis), and star-flower (Trientalis borealis) established under a single pioneer white pine.

Colonization and growth of conifers are accompanied by rapid environmental change and species turnover. Conditions for establishment of forest species are initially improved by colonization of pioneer trees, but eventually development of forest canopy and thick forest floor reduces the survival and recruitment of opendune species. Although the availability of light never becomes extremely low except under hemlock canopy, open-dune species are adapted to a high light environment and, consequently, may be especially vulnerable to light limitation (Bazzaz 1979). High amounts of litterfall under forest canopy can bury seedlings and small plants, preventing them from reaching sunlight (Sydes and Grime 1981, Monk and Gabrielson 1985, Beatty and Sholes 1988). Furthermore, a thick forest floor reduces seedling success by preventing the root radicle of germinating seedlings from reaching the mineral soil 
(Little and Moore 1949). Also, soil acidification and gradual thickening of the leached soil horizon may increase nutrient limitation as cationic nutrients are leached from the upper mineral soil. Precipitous decreases in soil $\mathrm{pH}$ and in $\mathrm{Ca}$ and $\mathrm{Mg}$ pools follow forest development and coincide with the loss of open-dune species. Plant distributions have been frequently correlated with soil $\mathrm{pH}$ and cation availability (Hope Simpson 1938, Rorison 1967, Grime 1979).

\section{Diversity-environment relations}

Changes in species richness across various environmental gradients related to productivity are consistent with observations that changes in the availability of light, soil moisture, N, P, and cationic nutrients may influence primary succession. Successional trajectories along the unimodal diversity-environment relationships indicate that diversity may be limited by low soil moisture, low soil $\mathrm{N}$, and colonization constraints during early primary succession (25-345 yr) and by low availability of light and/or base cations in established forest (345-2375 yr). Unlike these unimodal relationships, the linear diversity-soil $P$ relationship suggests that low $\mathrm{P}$ availability may limit diversity throughout the dune chronosequence. For a given quantity of soil $\mathrm{P}$, a habitat between 25 and $285 \mathrm{yr}$ will have fewer species than a habitat older than $285 \mathrm{yr}$, which suggests that a second factor in combination with low $\mathrm{P}$ availability, such as low $\mathrm{N}$ availability or colonization constraints, limits diversity during early primary succession.

Unimodal diversity-productivity relations have been described for a variety of plant communities (see Tilman and Pacala 1993) and several hypotheses have been proposed to explain the pattern. There is consensus that the initial increase in diversity along a productivity gradient is associated with ameliorating environmental conditions that allow more species to establish and persist (Rosenzweig 1995). It is the decrease in diversity at high productivity that requires explanation. Grime (1973) suggests that the intensity of competition is greater at high productivity, consequently only the best competitors are present. Newman (1973) asserts that there are more ways for a plant to be successful in habitats of low and intermediate productivity than in high productivity habitats where light is limiting. Tilman and Pacala (1993) predict that heterogeneity in resource supply rates is greatest at intermediate levels of productivity allowing the coexistence of more species.

At WSP, diversity-environment relations indicate that peak diversity occurs when no single resource is in extremely low supply. Therefore, no single environmental constraint is of overwhelming importance and species with different competitive strengths successfully compete. Thus as proposed by Newman (1973), high diversity may result from there being many different ways of being successful.

\section{CONCLUSions}

Clear patterns of primary succession and forest development are documented across the the dune chronosequence. The clarity of these patterns is associated with the regularity of dune formation and with similar initial conditions of parent materials, topography, and species pool during development of the chronosequence. Patterns of species turnover and compositional convergence as well as changes in species diversity, biomass accumulation, net ecosystem production, soil development, nutrient uptake, and nutrient cycling indicate that primary succession occurs across the youngest thirteen dune ridges ranging in age between 25 and 440 yr. Species richness varies unimodally with increasing dune age and along gradients of aboveground biomass, soil moisture, soil $\mathrm{N}$, soil $\mathrm{Ca}$, and soil $\mathrm{Mg}$, but linearly along a soil $\mathrm{P}$ gradient. Aboveground biomass, soil organic matter, and ecosystem $\mathrm{C}$ accumulate in a logistic manner, whereas nutrients are exponentially depleted from the upper mineral soil. The development of mixed white pine-red pine forest requires $\sim 300 \mathrm{yr}$ following the colonization of conifers and is accompanied by pronounced changes in ecosystem properties as well as in environmental constraints that potentially influence the distributions and abundances of plant species.

The dune chronosequence represents a complex environmental gradient along which plant species are differentially affected by changing environmental constraints. The early-successional environment is characterized by potential physical stress related to sand movement, nutrient stress, and colonization limitation, whereas the late-successional environment is characterized by competition for light, competition for soil nutrients, and recruitment limitation during later succession. Field experiments can determine which potential environmental constraints are important mechanisms of succession.

\section{ACKNOWLEDGMENTS}

Many students and faculty members at the University of Minnesota, the University of Michigan Biological Station, and Duke University contributed to this paper through discussion. I would like to acknowledge my dissertation committee at the University of Minnesota and thank them for providing intellectual guidance and support: David Tilman, Margaret Davis, Herbert Wright, Jr., John Pastor, Kerry Kelts, and Frank Martin. Much thanks to Phil Camill, Kathy Claerr, Jim Clark, Adrien Finzi, Deb Lawrence, Jason McLachlan, Jackie Mohan, Chris Paciorek, Bill Schlesinger, Miles Silman, David Tilman, Pete Wycoff, and four anonymous referees for providing constructive comments on the manuscript. Funding for this research was provided by the Graduate School of the University of Minnesota, the Dayton-Wilkie Fund of the Bell Museum of Natural History, the National Science Foundation Dissertation Improvement Award (DEB9310785), the NSF Research Training Group at the University of Minnesota (DIR-9014277), a Mellon Foundation grant to David Tilman, and the University of Michigan Biological Station. Special thanks are due James A. Teeri, Director of the University of Michigan Biological Station, for procuring funds for the initial radiocarbon dates. I also thank Rob Com- 
stock and Bob Pintal of the Michigan DNR for their cooperation and interest in this research. Lastly, I thank Bob Van de Kopple of the University of Michigan Biological Station for expert field assistance.

\section{Literature Cited}

Abrams, M. D. 1992. Fire and the development of oak forests. Bioscience 42:346-353.

Allen, E. B., and M. F. Allen. 1988. Facilitation of succession by the nonmycotrophic colonizer Salsola kali on a harsh site: effects of mycorrhizal fungi. American Journal of Botany 75:257-266.

Aplet, G. H., and P. M. Vitousek. 1994. An age-altitude matrix analysis of Hawaiian rain-forest succession. Journal of Ecology 82:137-147.

Auclair, A. N., and F. G. Goff. 1971. Diversity relations of upland forests in the western Great Lakes area. American Naturalist 105:499-528.

Bazzaz, F. A. 1979. The physiological ecology of plant succession. Annual Review of Ecology and Systematics 10: 351-371.

Beatty, S. W., and O. D. V. Sholes. 1988. Leaf litter effect on plant species composition of deciduous forest treefal pits. Canadian Journal of Forest Research 18:553-559.

Bierzychudek, P. 1982. Life histories and demography of shade-tolerant temperate forest herbs: a review. New Phytologist 90:757-776.

Binkley, D., and S. C. Hart. 1989. The components of nitrogen availability assessments in forest soils. Advances in Soil Science 10:57-112.

Bormann, B. T., and R. C. Sidle. 1990. Changes in productivity and distribution of nutrients in a chronosequence at Glacier Bay National Park, Alaska. Journal of Ecology 78: 561-578.

Bormann, F. H., and G. E. Likens. 1979. Pattern and process in a forested ecosystem. Springer-Verlag, New York, New York, USA.

Brewer, R. 1980. A half-century of changes in the herb layer of a climax deciduous forest in Michigan. Journal of Ecology 82:137-147.

Brimhall, G. H., O. A. Chadwick, C. J. Lewis, W. Compston, I. S. Williams, K. J. Danti, W. E. Dietrich, M. E. Power, D. Hendricks, and J. Bratt. 1991. Deformational mass transport and invasive processes in soil evolution. Science 255:695-702.

Brunig, E. F. 1973. Species richness and stand diversity in relation to site and succession of forests in Sarawak and Brunei (Borneo). Amazonia 3:293-320.

Cairns, J., Jr. 1980. The recovery process in damaged ecosystems. Ann Arbor Science, Ann Arbor, Michigan, USA

Changnon, S. A., Jr., and D. M. A. Jones. 1972. Review of the influences of the Great Lakes on weather. Water Resources Research 8:360-371.

Chapin, F. S., III. 1993. Physiological controls over plant establishment in primary succession. Pages $161-178$ in J. Miles and D. W. H. Walton, editors. Primary succession on land. Blackwell University Press, Oxford, UK.

Chapin, F. S., III, L. R. Walker, C. L. Fastie, and L. C. Sharman. 1994. Mechanisms of primary succession following deglaciation at Glacier Bay, Alaska. Ecological Monographs 64:149-175.

Christensen, N. L., and R. K. Peet. 1984. Convergence during secondary forest succession. Journal of Ecology $\mathbf{7 2}$ $25-36$.

Clements, F. H. 1916. Plant succession. Publication 242. Carnegie Institute, Washington, D.C., USA.

Cole, C. V., and R. D. Heil. 1981. Phosphorus effects on terrestrial nitrogen cycling. Pages 363-374 in F. E. Clark and T. Rosswall, editors. Terrestrial nitrogen cycles. Ecological Bulletins, Volume 33, Stockholm, Sweden.

Connell, J. H., and R. O. Slatyer. 1977. Mechanisms of suc- cession in natural communities and their role in community stability and organization. American Naturalist 111:11191144.

Cornish, P. S., and R. J. Raison. 1977. Effects of phosphorus and plants on nitrogen mineralization in three grassland soils. Plant and Soil 47:289-295.

Cowles, H. C. 1899. The ecological relations of the vegetation on the sand dunes of Lake Michigan. Botanical Gazette 27:95-117, 167-202, 281-308, 361-391.

Crow, T. R. 1988. Reproductive mode and mechanisms for self-replacement of northern red oak: a review. Forest Science 34:19-40.

Davis, M. B. 1989. Lags in vegetation response to greenhouse warming. Climatic Change 15:75-82.

Davy, A. J., and M. E. Figueroa. 1993. The colonization of strandlines. Pages 113-131 in J. Miles and D. W. H. Walton, editors. Primary succession on land. Blackwell Scientific, London, UK.

De Steven, D. 1991a. Experiments on mechanisms of tree establishment in old-field succession: seedling emergence. Ecology 72:1066-1075.

- 1991b. Experiments on mechanisms of tree establishment in old-field succession: seedling survival and growth. Ecology 72:1076-1088.

Disraeli, D. J. 1984. The effect of sand deposits on the growth and morphology of Ammophila breviligulata. Journal of Ecology 72:145-154.

Dott, E. R., and D. Mickelson. 1995. Lake Michigan water levels and the development of Holocene beach-ridge complexes at Two Rivers, Wisconsin: stratigraphic, geomorphic, and radiocarbon evidence. Geological Society of America Bulletin 107:286-296.

Drake, D. R., and D. Mueller-Dombois. 1993. Population development of rain forest trees on a chronosequence of Hawaiian lava flows. Ecology 74:1012-1019.

Drury, W. H., and I. C. T. Nisbet. 1973. Succession. Journal of the Arnold Arboretum 54:331-368.

Duffy, D. C., and A. J. Meier. 1992. Do Appalachian herbaceous understories ever recover from clearcutting? Conservation Biology 6:196-201.

Eichenlaub, V. L., J. R. Harmon, F. V. Nurnberger, and H. J. Stolle. 1990. The climatic atlas of Michigan. University of Notre Dame Press, Notre Dame, Indiana, USA.

Fastie, C. L. 1995. Causes and ecosystem consequences of multiple pathways of primary succession at Glacier Bay, Alaska. Ecology 76:1899-1916.

Forcella, F., and T. Weaver. 1977. Biomass and productivity of the subalpine Pinus albicaulis-Vaccinium scoparium association in Montana, USA. Vegetatio 35:95-105.

Franzmeier, D. P., and E. P. Whiteside. 1963. A chronosequence of podzols in northern Michigan. Michigan Quarterly Bulletin 46:2-57.

Gill, D. S., and P. L. Marks. 1991. Tree and shrub seedling colonization of old fields in central New York. Ecological Monographs 61:183-205.

Gorham, E., P. M. Vitousek, and W. A. Reiners. 1979. The regulation of chemical budgets over the course of terrestrial ecosystem succession. Annual Review of Ecology and Systematics 10:53-84.

Grigal, D. F., and L. F. Ohmann. 1992. Carbon storage in upland forests of the Lake States. Soil Science Society of America Journal 56:935-943.

Grime, J. P. 1973. Competitive exclusion in herbaceous vegetation. Nature 242:344-347.

. 1979. Plant strategies and vegetation processes. John Wiley and Sons, Chichester, UK.

Harcombe, P. A., M. E. Harmon, and S. E. Greene. 1990. Changes in biomass and production over 53 years in a coastal Picea sitchensis-Tsuga heterophylla forest ap- 
proaching maturity. Canadian Journal of Forest Research 20:1602-1610.

Harris, D., and A. J. Davy. 1987. Seedling growth in Elymus farctus after episodes of burial with sand. Annals of Botany 60:587-593.

Heinselman, M. L. 1981. Fire and succession in the conifer forests of northern North America. Pages 374-405 in D. C. West, H. H. Shugart, and D. B. Botkin, editors. Forest succession: concepts and applications. Springer-Verlag, New York, New York, USA

Herbert, D. A., and J. H. Fownes. 1995. Phosphorus limitation of forest leaf area and net primary production on a highly weathered soil. Biogeochemistry 29:223-235.

Hibbs, D. E. 1983. Forty years of forest succession in central New England. Ecology 64:1394-1401.

Hope Simpson, J. F. 1938. A chalk flora on the lower Greensand: Its use in interpreting the calcicole habit. Journal of Ecology 26:218-235.

Jacobson, G. L., and H. J. B. Birks. 1980. Soil development on recent end moraines of the Klutlan Glacier, Yukon Territory, Canada. Quaternary Research 14:87-100.

Johnson, W. C., R. L. Burgess, and W. R. Keammerer. 1976. Forest overstory vegetation and environment on the Missouri River floodplain in North Dakota. Ecological Monographs 46:59-84.

Kellman, M., and M. Kading. 1992. Facilitation of tree seedling establishment in a sand dune succession. Journal of Vegetation Science 3:679-688.

Kira, T., and T. Shidei. 1967. Primary production and turnover of organic matter in different forest ecosystems of the western Pacific. Japanese Journal of Ecology 17:70-87.

Kurz, W. A., S. J. Beukema, and M. J. Apps. 1996. Estimation of root biomass and dynamics for the carbon budget model of the Canadian forest sector. Canadian Journal of Forest Research 26:1973-1979.

Lajtha, K., and W. H. Schlesinger. 1988. The biogeochemistry of phosphorus cycling and phosphorus availability along a desert soil chronosequence. Ecology 69:24-39.

Lichter, J. 1995. Lake Michigan beach-ridge and dune development, lake level, and variability in regional water balance. Quaternary Research 44:181-189.

. 1997. AMS radiocarbon dating of Lake Michigan beach-ridge and dune development. Quaternary Research 48: $137-140$.

1998. Rates of weathering and chemical depletion in surface soils across a chronosequence of Lake Michigan sand dunes. Geoderma, 85:255-282.

Little, S., and E. B. Moore. 1949. The ecological role of prescribed burns in the pine-oak forests of southern New Jersey. Ecology 30:223-233.

Loucks, O. L. 1970. Evolution of diversity, efficiency, and community stability. American Zoologist 10:17-25.

Margalef, R. 1963. On certain unifying principles in ecology. American Naturalist 97:357-374.

Marks, P. L. 1974. The role of pin cherry in the maintenance of stability in northern hardwood ecosystems. Ecological Monographs 44:73-88.

Matthews, J. A. 1979. A study of the variability of some successional and climax plant assemblage-types using multiple discriminant analysis. Journal of Ecology 67:255-271.

Maun, M. A. 1996. The effects of burial by sand on survival and growth of Calamovilfa longifolia. Ecoscience 3:93100 .

Maun, M. A., and J. Lapierre. 1984. The effects of burial by sand on Ammophila breviligulata. Journal of Ecology 72:827-839.

McClanahan, T. R. 1986. The effect of a seed source on primary succession in a forest ecosystem. Vegetatio $\mathbf{6 5}$ : $175-178$

McCune, B., and T. F. H. Allen. 1984. Will similar forests develop on similar sites? Canadian Journal of Botany $\mathbf{6 3}$ : 367-374.

McDonnell, M. J., and E. W. Stiles. 1983. The structural complexity of old field vegetation and the recruitment of bird-dispersed plant species. Oecologia 56:109-116.

McGill, W. B., and C. V. Cole. 1981. Comparative aspects of cycling of organic $\mathrm{C}, \mathrm{N}, \mathrm{S}$ and $\mathrm{P}$ through soil organic matter. Geoderma 26:267-286.

Meier, A. J., S. P. Bratten, and D. C. Duffy. 1995. Possible ecological mechanisms for loss of vernal-herb diversity in logged eastern deciduous forests. Ecological Applications 5:935-946.

Monk, C. D. 1967. Tree species diversity in the eastern deciduous forest with particular reference to north central Florida. American Naturalist 101:173-187.

Monk, C. D., and F. C. Gabrielson. 1985. Effects of shade, litter, and root competition on old-field vegetation in South Carolina. Bulletin of the Torrey Botanical Club 112:383392.

National Atmospheric Deposition Program. 1994. NADP/ NTN annual data summary. Precipitation chemistry in the United States. Natural Resource Ecology Laboratory, Colorado State University, Fort Collins, Colorado, USA.

Nelson, D. W., and L. E. Sommers. 1982. Total carbon, organic carbon, and organic matter. Pages 539-579 in A. L. Page, R. H. Miller, and D. R. Keeney, editors. Methods of soil analysis, number 9. American Society of Agronomy, Soil Science Society of America. Madison, Wisconsin, USA.

Newman, E. I. 1973. Competition and diversity in herbaceous vegetation. Nature 244:310.

Nurnberger, F. V. 1996. Climate of Michigan summaries. Michigan Department of Agriculture and Michigan State University, Lansing, Michigan, USA.

Odum, E. P. 1969. The strategy of ecosystem development. Science 164:262-270.

Olson, J. S. 1958a. Lake Michigan dune development 3. Lake-level, beach, and dune oscillations. Journal of $\mathrm{Ge}-$ ology 66:473-483.

- 1958b. Rates of succession and soil changes on southern Lake Michigan sand dunes. Botanical Gazette 119: $125-170$.

Ostfeld, R. S., R. H. Manson, and C. D. Canham. 1997. Effects of rodents on survival of tree seeds and seedlings invading old fields. Ecology 78:1531-1542.

Pastor, J., J. D. Aber, and J. M. Mellilo. 1983/1984. Biomass prediction using generalized allometric regressions for some northeast tree species. Forest Ecology and Range Management 7:265-274.

Pastor, J., J. D. Aber, C. A. McClaughterty, and J. M. Melillo. 1984. Aboveground production and $\mathrm{N}$ and $\mathrm{P}$ cycling along a nitrogen mineralization gradient on Blackhawk Island, Wisconsin. Ecology 65:256-268.

Pearson, J. A., D. H. Knight, and T. J. Fahey. 1987. Biomass and nutrient accumulation during stand development in Wyoming lodgepole pine forests. Ecology 6:1966-1973.

Peet, R. K. 1978. Forest vegetation of the Colorado front range: patterns of species diversity. Vegetatio 37:65-78.

. 1992. Community structure and ecosystem function. Pages 103-151 in D. C. Glenn-Lewin, R. K. Peet, and T. T. Veblen, editors. Plant succession: theory and prediction. Chapman and Hall, London, UK.

Peet, R. K., and N. L. Christensen. 1980. Succession: a population process. Vegetatio 43:131-140.

Peterken, G. F., and M. Game. 1984. Historical factors affecting the number and distribution of vascular plant species in the woodlands of central Lincolnshire. Journal of Ecology 72:155-182.

Petty, W. H., P. A. Delcourt, and H. R. Delcourt. 1996. Holocene lake-level fluctuations and beach-ridge development 
along the northern shore of Lake Michigan, USA. Journal of Paleolimnology 15:147-169.

Pickett, S. T. A. 1989. Space-for-time substitution as an alternative to long-term studies. Pages $110-135$ in G. E. Likens, editor. Long-term studies in ecology. Springer-Verlag, New York, New York, USA.

Pickett, S. T. A., S. L. Collins, and J. J. Armesto. 1987 Models, mechanisms, and pathways of succession. Botanical Review 53:335-371.

Pielou, E. C. 1984. The interpretation of ecological data. John Wiley and Sons, New York, New York, USA.

Pye, K. 1990. Physical and human influences on coastal dune development between the Ribble and Mersey estuaries, northwest England. Pages 339-359 in K. F. Nordstrum, N P. Psuty, and R. W. G. Carter, editors. Coastal dunes: form and process. John Wiley and Sons, New York, New York, USA.

Raich, J. W., A. E. Russell, T. E. Crews, H. Farrington, and P. M. Vitousek. 1996. Both nitrogen and phosphorus limit plant production on young Hawaiian lava flows. Biogeochemistry 32:1-14.

Reiners, W. A., I. A. Worley, and D. B. Lawrence. 1971 Plant diversity in a chronosequence at Glacier Bay, Alaska. Ecology 52:55-69.

Rejmanek, M., R. Haagerova, and J. Haager. 1982. Progress of plant succession on the Paricutin Volcano: 25 years after activity ceased. American Midland Naturalist 108:194198.

Robertson, G. P., and P. M. Vitousek. 1981. Nitrification potentials in primary and secondary succession. Ecology 62:376-381.

Rorison, I. H. 1967. A seedling bioassay on some soils in the Sheffield area. Journal of Ecology 55:725-741.

Rosenzweig, M. L. 1995. Species diversity in space and time. Cambridge University Press, Cambridge, UK.

Ross, B. A., J. R. Bray, and W. H. Marshall. 1970. Effects of long-term deer exclusion on a Pinus resinosa forest in north-central Minnesota. Ecology 51:1088-1093.

Schiffman, P. M., and W. C. Johnson. 1989. Phytomass and detrital carbon storage during forest regrowth in the southeastern United States piedmont. Canadian Journal of Forest Research 19:69-78.

Schlesinger, W. H. 1977. Carbon balance in terrestrial detritus. Annual Review of Ecology and Systematics 8:5181.

Schoonmaker, P., and A. McKee. 1988. Species composition and diversity during secondary succession of coniferous forests in the western Cascade Mountains of Oregon. Forest Science 34:960-979.

Shafi, M. I., and G. A. Yarranton. 1973. Diversity, floristic richness, and species evenness during a secondary succession. Ecology 54:897-902.

Shugart, H. H. 1984. A theory of forest dynamics. SpringerVerlag, New York, New York, USA

Sprugel, D. G. 1984. Density, biomass, productivity, and nutrient-cycling changes during stand development in wave-regenerated balsam fir forest. Ecological Monographs 54:165-186.

1985. Natural disturbance and ecosystem energetics. Pages 335-352 in S. T. A. Pickett and P. S. White, editors. The ecology of natural disturbance and patch dynamics. Academic Press, San Diego, California, USA.

Spurr, S. H., and J. H. Zumberge. 1956. Late Pleistocene features of Cheboygan and Emmet Counties, Michigan. American Journal of Science 254:96-109.

Stevens, P. R., and T. W. Walker. 1970. The chronosequence concept and soil formation. Quarterly Review of Biology 45:333-350

Stone, E. L., and R. Kszystyniak. 1977. Conservation of potassium in the Pinus resinosa ecosystem. Science 198: 192-194.

Sydes, C., and J. P. Grime. 1981. Effects of tree leaf litter on herbaceous vegetation in deciduous woodland. II. An experimental investigation. Journal of Ecology 69:249262.

Sykes, M. T., and J. B. Wilson. 1990. An experimental investigation into the response of New Zealand sand dune species to different depths of burial by sand. Acta Botanica Neerlandica 39:171-181.

Tate, K. R., and I. Salcedo. 1988. Phosphorus control of soil organic matter accumulation and cycling. Biogeochemistry 5:99-107.

Thompson, T. A. 1992. Beach-ridge development and lakelevel variation in southern Lake Michigan. Sedimentary Geology 80:305-318.

Tilman, D. 1985. The resource-ratio hypothesis of plant succession. American Naturalist 125:827-852.

. 1988. Plant strategies and the dynamics and structure of plant communities. Princeton University Press, Princeton, New Jersey, USA.

1990. Constraints and tradeoffs: toward a predictive theory of competition and succession. Oikos 58:3-15.

Tilman, D., and S. Pacala. 1993. The maintenance of species richness in plant communities. Pages 13-25 in R. E. Ricklefs and D. Schluter, editors. Species diversity in ecological communities. University of Chicago Press, Chicago, Illinois, USA.

van Dorp, D., R. Boot, and E. van der Maarel. 1985. Vegetation succession on the dunes near Ostvoorne, The Netherlands, since 1934, interpreted from air photographs and vegetation maps. Vegetatio 58:123-136.

Vitousek, P. M., T. Fahey, D. W. Johnson, and M. J. Swift. 1988. Element interactions in forest ecosystems: succession, allometry and input-output budgets. Biogeochemistry 5:7-34.

Vitousek, P. M., and R. W. Howarth. 1991. Nitrogen limitation on land and in the sea: how can it occur? Biogeochemistry 13:87-115.

Vitousek, P. M., and W. A. Reiners. 1975. Ecosystem succession and nutrient retention: a hypothesis. Bioscience 25: 376-381.

Vitousek, P. M., L. R. Walker, L. D. Whiteaker, and P. A. Matson. 1993. Nutrient limitations to plant growth during primary succession in Hawaii Volcanoes National Park. Biogeochemistry 23:197-215.

Walker, L. R. 1993. Nitrogen fixers and species replacements in primary succession. Pages $249-272$ in J. Miles and D. W. H. Walton, editors. Primary succession on land. Blackwell Scientific, Oxford, UK.

Walker, L. R., and F. S. Chapin, III. 1986. Physiological controls over seedling growth in primary succession on an Alaskan floodplain. Ecology 67:1508-1523.

Walker, L. R., and F. S. Chapin, III. 1987. Interactions among processes controlling successional change. Oikos 50:131135.

Walker, L. R., J. C. Zasada, and F. S. Chapin, III. 1986. The role of life history processes in primary succession on an Alaskan floodplain. Ecology 67:1243-1253.

Walker, T. W., and J. K. Syers. 1976. The fate of phosphorus during pedogenesis. Geoderma 15:1-19.

Weller, S. G. 1989. The effect of disturbance scale on sand dune colonization by Lithospermum caroliniense. Ecology 70:1244-1251.

Whittaker, R. H., F. H. Bormann, G. E. Likens, and T. G. Siccama. 1974. The Hubbard Brook ecosystem study: forest biomass and production. Ecological Monographs 44: 233-252. 
Whittaker, R. J., M. B. Bush, and K. Richards. 1989. Plant recolonization and vegetation succession on the Krakatau Islands, Indonesia. Ecological Monographs 59:59-123.

Wood, D. M., and R. del Moral. 1987. Mechanisms of early primary succession in subalpine habitats on Mount St. Helens. Ecology 68:780-790.

Wood, D. M., and W. F. Morris. 1990. Ecological constraints to seedling establishment on the pumice plains, Mount St. Helens, Washington. American Journal of Botany 77:14111418.

Zhang, J., and M. A. Maun. 1990. Effects of sand burial on seed germination, seedling emergence, survival, and growth of Agropyron psammophilum. Canadian Journal of Botany 68:304-310. 